US Army Corps

of Engineers ${ }_{\circledast}$

Engineer Research and

Development Center

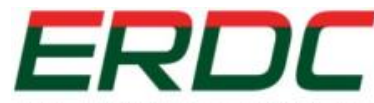

INNOVATIVE SOLUTIONS

for a safer, better world

\title{
Contingency Base Camp Solid Waste Generation
}

Stephen D. Cosper, H. Garth Anderson, Kurt Kinnevan, and Byung J. Kim
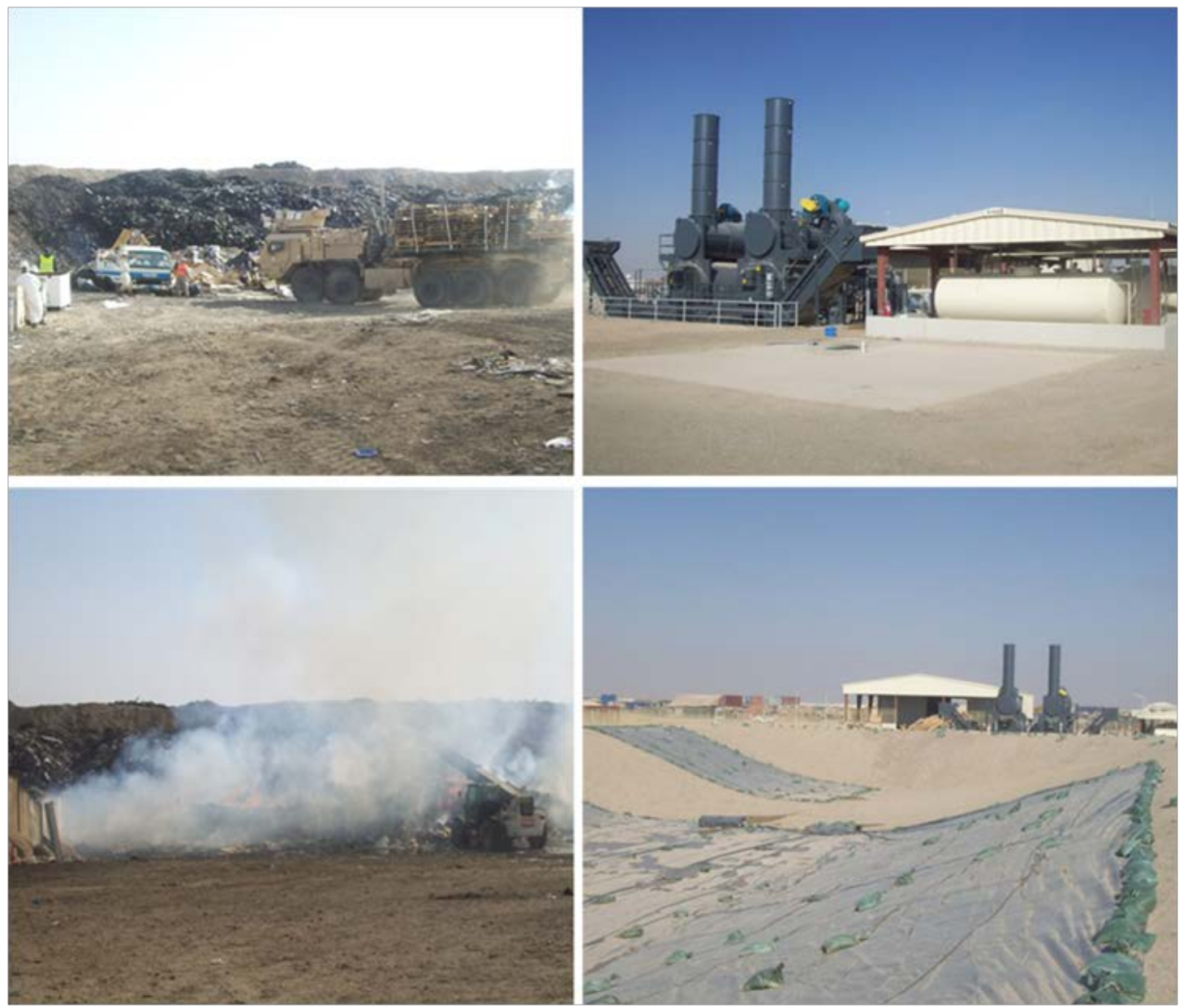
The U.S. Army Engineer Research and Development Center (ERDC) solves the nation's toughest engineering and environmental challenges. ERDC develops innovative solutions in civil and military engineering, geospatial sciences, water resources, and environmental sciences for the Army, the Department of Defense, civilian agencies, and our nation's public good. Find out more at www.erdc.usace.army.mil.

To search for other technical reports published by ERDC, visit the ERDC online library at http://acwc.sdp.sirsi.net/client/default. 


\section{Contingency Base Camp Solid Waste Generation}

Stephen D. Cosper, H. Garth Anderson, Kurt Kinnevan, and Byung J. Kim

Construction Engineering Research Laboratory (CERL)

US Army Engineer Research and Development Center

2902 Newmark Dr.

Champaign, IL 61822-1076

Final Report

Approved for public release; distribution is unlimited.

Prepared for Headquarters, US Army Corps of Engineers

Washington, DC 20314-1000 


\section{Abstract}

Solid waste management is an important engineering function at Forward Operating Bases (FOBs). Due to the contingency nature of base operations and daily life at the FOB, waste generation is likely to be always higher than Continental United States (CONUS) on a per soldier basis. To improve operational effectiveness and efficiency, there is a need to gather baseline information on which to evaluate the performance of new technologies and approaches to solid waste management. To fill this data gap, the Army Study Program funded a group of studies for power, water, and waste management. This specific work characterized and quantified solid waste generation, which includes septage ("blackwater") generation, at the "per soldier" and base camp level.

DISCLAIMER: The contents of this report are not to be used for advertising, publication, or promotional purposes. Citation of trade names does not constitute an official endorsement or approval of the use of such commercial products. All product names and trademarks cited are the property of their respective owners. The findings of this report are not to be construed as an official Department of the Army position unless so designated by other authorized documents. 


\section{Table of Contents}

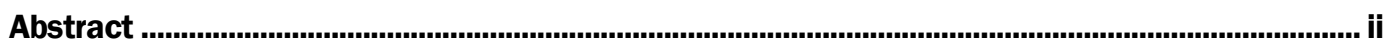

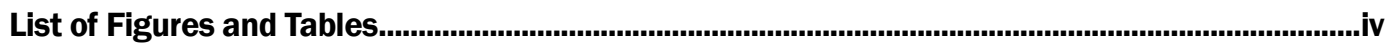

Preface ............................................................................................................................................................

1 Introduction

1.1 Background

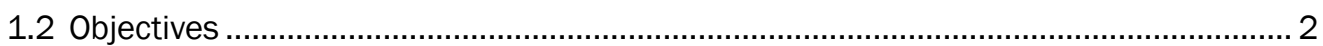

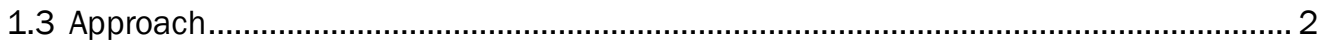

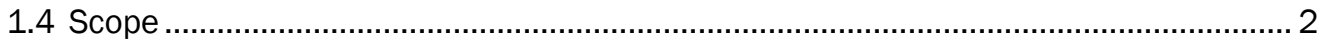

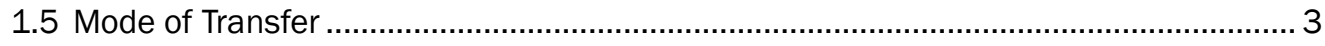

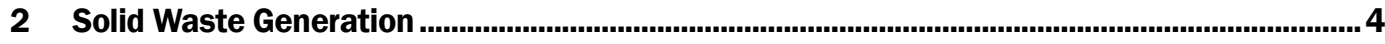

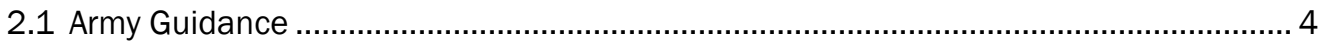

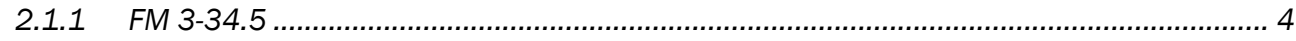

2.1.2 GSTM 3-34.56 Waste Management Operations ........................................................ 4

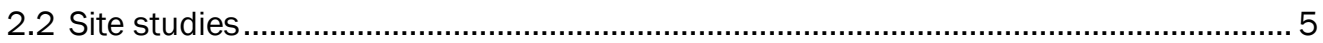

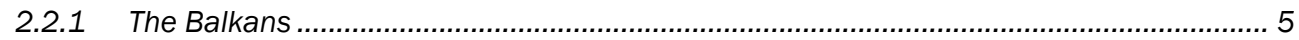

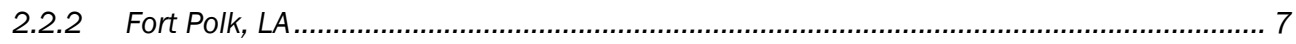

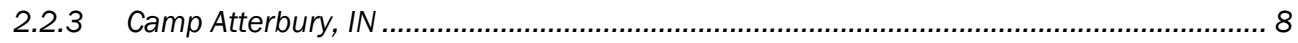

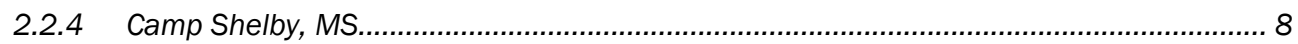

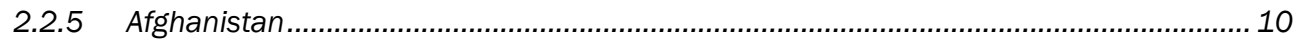

2.3 Comparison of Solid Waste Generation Rates ..................................................... 18

3 Blackwater Generation ..........................................................................................................20

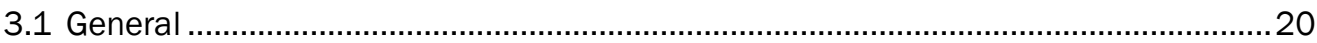

3.2 Camp Atterbury......................................................................................... 21

4 Conclusion .....................................................................................................................................22

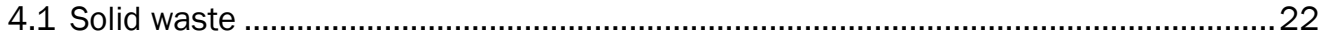

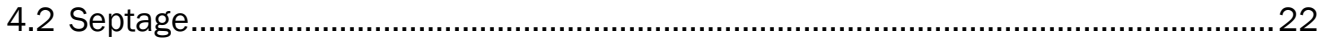

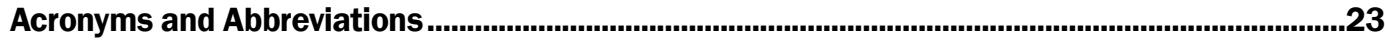

References ................................................................................................................................25

Report Documentation Page (SF 298) ..............................................................................................28 


\section{List of Figures and Tables}

\section{Figures}

1 Personnel search through mixed waste during June 2003 Eagle Base Survey ..................... 5

2 Barracks at Camp Atterbury, FOB 3 ...................................................................................... 9

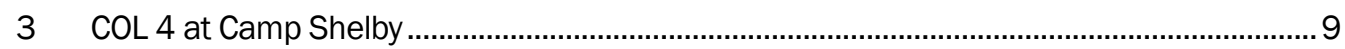

4 Solid waste collection at Camp Phoenix.....................................................................................11

5 Solid waste collection at New Kabul compound ...............................................................11

6 Recycling bins at New Kabul Compound ..........................................................................12

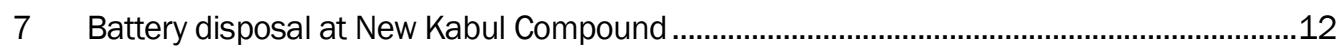

8 Salerno solid waste disposal operations............................................................................13

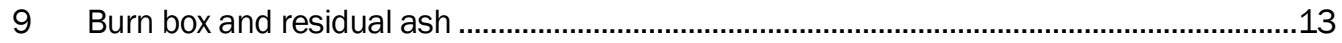

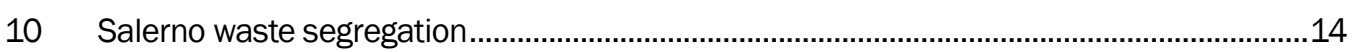

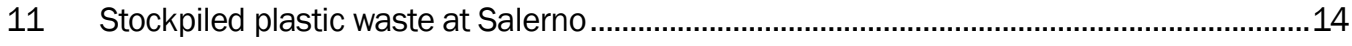

12 Load inspection at Camp Leatherneck ………..........................................................15

13 Waste segregation at Camp Leatherneck .........................................................................16

14 Camp Leatherneck active burn operation ..................................................................16

15 Another view of active burn operation at Camp Leatherneck ..............................................17

16 Incinerator under construction at Camp Leatherneck ........................................................17

17 Another view of incinerator construction at Camp Leatherneck.........................................18

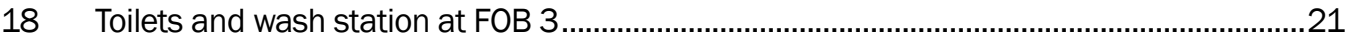

\section{Tables}

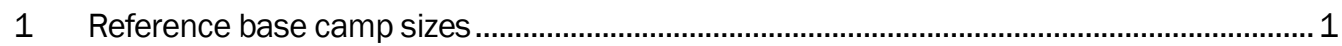

2 Non-hazardous solid waste generation rates from GSTM 3-34.56 ..................................... 5

3 Base camp solid waste production by soldier ................................................................. 6

4 Results of two characterization studies in the Balkans ........................................................ 7

5 Solid waste generated at the Force Providers training site ................................................. 8

6 Solid waste generation at Camp Atterbury, FOB 3 …………………………...................

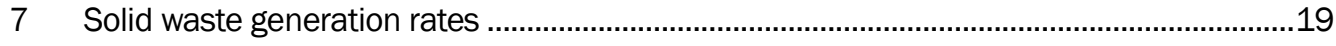

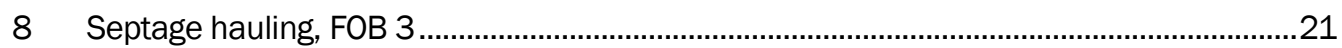




\section{Preface}

This study was conducted for Assistant Secretary of the Army for Acquisition, Logistics, and Technology (ASAALT) under Project AMSCO 622784T4100, "Military Facilities Engineering Technology," Work Unit 122G16, "Forward Operating Bases." The technical monitor was J ohn Munroe, US Army Natick RD\&E Center, PM-FSS.

The work was managed and executed by the Environmental Processes Branch (CN-E) of the Installations Division (CN), Construction Engineering Research Laboratory (CERL). The CERL principal investigator was $\mathrm{H}$. Garth Anderson. Deborah R. Curtin is Chief, CEERD-CN-E, and Dr. J ohn T. Bandy is Chief, CEERD-CN. The associated Technical Director was Alan Anderson, CEERD-CV-T. The Director of ERDC-CERL is Dr. Ilker R. Adiguzel.

CERL is an element of the US Army Engineer Research and Development Center (ERDC), US Army Corps of Engineers. The Commander and Executive Director of ERDC is COL Kevin J. Wilson, and the Director of ERDC is Dr. J effery P. Holland. 


\section{Introduction}

\subsection{Background}

Over the past few decades, Army training and doctrine has evolved to emphasize military operational aspects (i.e., mission), and to de-emphasize aspects of soldier and camp sustainment. The rationale for this shift is that, in short term campaigns, soldiers can deploy with or take care of their own support needs, while long-term deployments will be supported by contractor staff. This approach has proven generally effective in Iraq and Afghanistan.

However, as these conflicts and deployments have continued, some flaws in this rationale have come to light. First, in larger base camps where contractors provide all support services, there is little consistent knowledge throughout the Army on quantities of utilities used (or required). Contractors have little incentive to collect and submit such information. This lack of data makes camp planning difficult and provides little opportunity for economizing measures since it is hard to get the "big picture" for planning purposes. Second, contractor service at the smaller, more remote camps is limited. Consequently, soldiers who have had little training for the tasks must take on engineering and housekeeping functions, which takes time away from mission activities.

To improve operational effectiveness and efficiency, there is a need to gather baseline information on which to evaluate the performance of new technologies and approaches. To fill this data gap, the Army Study Program funded a group of studies for power, water, and waste management. This specific work was undertaken to characterize and quantify solid waste generation, which includes septage ("blackwater") generation, "per soldier" and at the base camp level. Table 1 lists the camp sizes considered in this report.

Table 1. Reference base camp sizes.

\begin{tabular}{|l|c|c|c|}
\hline Type & Military & Civilians & PAX \\
\hline Company & 120 & 0 & 120 \\
\hline Battalion & 600 & 400 & 1,000 \\
\hline Brigade & 6,000 & 6,000 & 12,000 \\
\hline
\end{tabular}




\subsection{Objectives}

The overall objectives of this work are to improve utility and sustainment protocols at Contingency Base Camps. The specific objective of this initial stage of work (and the first logical step) is to characterize and quantify solid waste generation, which includes septage ("blackwater") generation, "per soldier" and at the base camp level.

\subsection{Approach}

The objectives of this work were met in the following steps:

1. Army guidance documents and open literature were reviewed for any waste generation data or descriptions of relevant base camp waste management practices.

2. Researchers gathered data on current practices through:

a. electronic communication with installation managers

b. interviews with personnel who had recently returned from performing Directorate of Public Works (DPW) type functions in theater

c. visits to Continental United States (CONUS) training forward operating bases (FOBs) at Camp Atterbury, IN and Camp Shelby, MS to assess their "realism" and to collect utility data.

d. A site visit by a CERL researcher deployed to Afghanistan as an Army Reservist, who interviewed base camp personnel and made observations on solid waste management.

3. Results of this work were compiled and analyzed, and conclusions were drawn.

\subsection{Scope}

Two main constraints limit the depth of information that collected for this report. First, much of the waste management service to the deployed Army is provided by contract; therefore, data on these activities is not forthcoming. Secondly, researchers are limited in the length of time spent in-theater for first hand observations of waste management practices.

Nevertheless, information in this report should be widely applicable, at least in terms of methodology. Information presented herein is intended to apply to current Army deployments. While technology could be fielded to rapidly change solid waste management practices, solid waste generation rates would be less likely to vary in future deployments. 


\subsection{Mode of Transfer}

It is anticipated that the results of this study will inform and support:

- several Major Objectives of the 2008 Army Campaign Plan as outlined in the 18 J une 2008 Execution Order (EXORD) (HQDA 2008)

- the current Base Camp Integrated Capabilities Development Team (ICDT) assessments that the US Army Maneuver Support Center (MANSCEN) are performing for the US Army Training and Doctrine Command (TRADOC)

- the development of interoperable systems across the US Department of Defense (DOD).

This report will be made accessible through the World Wide Web (WWW) at URLs: http://www.cecer.army.mil and http://libweb.erdc.usace.army.mil 


\section{Solid Waste Generation}

This Chapter presents data gathered on generation rates and types of solid wastes (i.e., trash) at base camps.

\subsection{Army Guidance}

\subsubsection{FM 3-34.5}

Field Manual (FM) 3-34.5, Environmental Considerations (HQDA 2010) contains planning guidance for integrating environmental activities into general operating plans. This manual does not contain information regarding generation rates of wastes.

\subsubsection{GSTM 3-34.56 Waste Management Operations}

General Subject Technical Manual (GSTM) 3-34.56 (which, at the time of this writing is an initial draft not ready for implementation) is intended to provide information to base camp planners to enable them to provide the necessary facilities for solid waste management at future base camps. The manual also provides planning information for the management of black water. GSTM 3-34.56 quantifies solid water generation and black water generation rates in several contexts:

1. Preface, line 1: "A soldier in the field can generate 20 pounds of solid waste and 80 pounds of liquid waste per day."

2. Paragraph 3-21(Composting): "A base camp population of 2,500 can produce approximately 5,500 cubic meters, or 1,500 tons, of compostable solid waste (SW) (including sewage sludge) per year.

3. Paragraph 3-63 (Develop Preliminary Waste Estimates): "For units on the move or not situated in a base camp, planners use a generation rate of 4 pounds per person per day as a general rule of thumb.

4. Table 3-2, p. 3-14: This table presents planning factors for components of solid waste assuming none is being reused or recycled.

Table 2 lists the non-hazardous solid waste generation rates given in GSTM 3-34.56. 
Table 2. Non-hazardous solid waste generation rates from GSTM 3-34.56.

\begin{tabular}{|l|c|l|c|}
\hline \multicolumn{2}{|c|}{ Generation Rates "on the move" } & \multicolumn{2}{c|}{ Generation Rates in Base Camps } \\
\hline Component & Rate (lbs/person/day) & \multicolumn{1}{c|}{ Component } & Rate (Ibs/person/day) \\
\hline General refuse & 1.5 & Plastic bottles & 0.54 \\
\hline Food waste & 2.5 & Other plastic & 1.38 \\
\hline Total & 4 & Aluminum & 0.13 \\
\hline & & Cardboard & 1.45 \\
\hline & & Paper & 2.67 \\
\hline & & Food waste & 1.67 \\
\hline & Textiles & 0.26 \\
\hline & & Glass & 0.1 \\
\hline & & Scrap wood & 2.95 \\
\hline & & Miscellaneous & 2.3 \\
\hline & & Total & 18.2 \\
\hline
\end{tabular}

\subsection{Site studies}

\subsubsection{The Balkans}

\subsubsection{Base Camp Solid Waste Characterization Study}

ERDC/ CERL TR-06-24, Base Camp Solid Waste Characterization Study (Gerdes and J antzer 2006) characterizes nonhazardous solid wastes generated at Army base camps. The data in this report were obtained from solid waste characterization surveys of base camps in Bosnia, Kosovo, and Bulgaria. The report describes the nature of base camp solid waste and how solid waste management varies with mission maturity. It also documents the field surveys and other data sources used to compile the comprehensive solid waste characterization schedules. Figure 1 shows the solid waste sorting being done at Eagle Base, Tuzla, Bosnia in 2003.

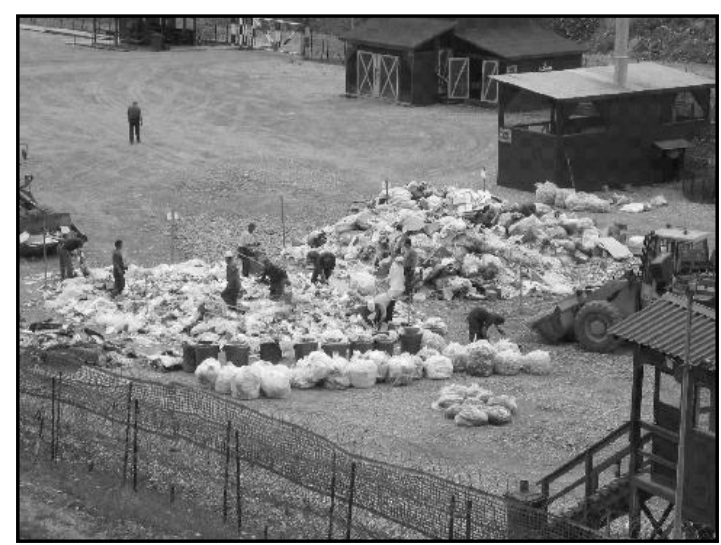

Source: Tucker et al. (2004).

Figure 1. Personnel search through mixed waste during June 2003 Eagle Base Survey. 
Table 3. Base camp solid waste production by soldier.

\begin{tabular}{|c|c|c|c|c|c|}
\hline Material & lb/yr/soldier & lb/day/soldier & $\mathrm{kg} / \mathrm{yr} /$ soldier & $\mathrm{kg} /$ day/soldier & $\%$ of total \\
\hline Plastic bottles* & 295 & 0.808 & 134 & 0.367 & $5.1 \%$ \\
\hline Polystyrene & 9.3 & 0.025 & 4.2 & 0.012 & $0.2 \%$ \\
\hline Other plastics & 143 & 0.392 & 65 & 0.178 & $2.5 \%$ \\
\hline Aluminum & 10 & 0.027 & 4.7 & 0.013 & $0.2 \%$ \\
\hline Other metals & 11 & 0.030 & 4.8 & 0.013 & $0.2 \%$ \\
\hline Corrugated paper & 349 & 0.956 & 158 & 0.433 & $6.0 \%$ \\
\hline Other paper & 179 & 0.490 & 81 & 0.222 & $3.1 \%$ \\
\hline Scrap wood & 4,151 & 11.373 & 1,883 & 5.159 & $72 \%$ \\
\hline Kitchen food waste & 328 & 0.899 & 149 & 0.408 & $5.7 \%$ \\
\hline Post-consumer food waste & 51 & 0.140 & 23 & 0.063 & $0.9 \%$ \\
\hline WWTP sludge (dry weight) ${ }^{* *}$ & 70 & 0.192 & 32 & 0.088 & $1.2 \%$ \\
\hline Sawdust & 47 & 0.129 & 21 & 0.058 & $0.8 \%$ \\
\hline Grass clippings & 39 & 0.107 & 18 & 0.049 & $0.7 \%$ \\
\hline Glass & 40 & 0.110 & 18 & 0.049 & $0.7 \%$ \\
\hline Textiles & 25 & 0.068 & 11 & 0.068 & $0.4 \%$ \\
\hline Medical waste & 13 & 0.036 & 6.1 & 0.036 & $0.2 \%$ \\
\hline Rubber & 3.9 & 0.011 & 1.8 & 0.011 & $0.1 \%$ \\
\hline Miscellaneous & 5.3 & 0.015 & 2.4 & 0.015 & $0.1 \%$ \\
\hline Total $^{* * *}$ & 5,769 & 15.8 & 2,617 & 7.2 & $100 \%$ \\
\hline \multicolumn{6}{|c|}{$\begin{array}{l}\text { * Reflects } 100 \% \text { drinking water distribution via disposable bottled water } \\
\text { ** WWTP sludge weight expressed as } 100 \% \text { solids - multiply by } 5 \text { for a cake and multiply by } 50 \text { for a liquid } \\
\text { *** Survey includes all discarded solid waste except hazardous waste, recycled scrap metal, and salvaged construction material and } \\
\text { equipment. } \\
\text { Above values do not reflect additional loadings due to Transfer of Authority (TOA) rotations (estimated to increase annual waste } \\
\text { production by approximately } 1 \text { month for bi-annual TOAs) } \\
\text { Above values are based on relatively short-term studies and reflect a population "snapshot." It is not known whether this table accurately } \\
\text { includes the fraction of solid wastes generated by host-nation contract employees and transient combatants. }\end{array}$} \\
\hline
\end{tabular}

Table 3 lists the comprehensive base camp waste characterization that was developed based on the evaluations of this study. The Wastewater Treatment Plant (WWTP) sludge production was based on studies at wastewater treatment plants at three base camps. Note that the most significant component is waste wood, which is primarily pallets, shipping crates, and construction/ demolition waste.

\subsubsection{Solid Waste Generation Rates at Army Base Camps}

The study described in the previous section characterized wastes generated by a camp that had recently transitioned from combat operations to stability operations. PWTB 200-1-51, Solid Waste Generation Rates at Army Base Camps (HQUSACE 2008) described a second study conducted in 2006 that characterized wastes generated by a camp that had matured to the extent that the infrastructure was largely semi-permanent and was 
capable of sustaining long-term missions. Table 4 lists the results of two characterization studies in the Balkans, side by side, for comparison.

\subsubsection{Fort Polk, LA}

Hughes Associates, Inc., conducted a study for the Research, Development, and Engineering Command (RDECOM) in J une 2000 to characterize wastes generated at the Force Provider training site at Fort Polk, LA. The study involved collecting and sorting wastes from the Force Provider camp over a 6-day period. The Force Provider camp at Fort Polk provided a living scenario similar to deployment for soldiers who trained there. However, several types of solid wastes were not generated at that training camp during that study that would be generated at an actual deployment, including shipping wastes, wastewater treatment solids, office wastes, plastic bottles, some metal waste, and textiles. The reasons for these differences are the short term nature of training, and that utilities at the Force Provider camp (including water supply and wastewater treatment) were provided by connections to the Fort Polk infrastructure. The wastes characterized from the Force Provider were primarily generated from the dining facility and the soldiers' quarters. Table 5 lists the reported generation rates.

Table 4. Results of two characterization studies in the Balkans.

\begin{tabular}{|l|c|c|c|c|c|c|}
\hline \multirow{2}{*}{ Component } & \multicolumn{3}{|c|}{ 2006 Data (Camp B) } & \multicolumn{3}{c|}{ 2003 Data (Camp A) } \\
\cline { 2 - 7 } & Ib/person/yr & Ib/person/day & Percent & Ib/person/yr & Ib/person/day & Percent \\
\hline Plastic bottles & 196 & 0.537 & 3.0 & 295 & 0.808 & 5.1 \\
\hline Other plastic & 502 & 1.375 & 7.6 & 143 & 0.392 & 2.5 \\
\hline Aluminum & 46 & 0.126 & 0.7 & 10 & 0.027 & 0.2 \\
\hline Light metal & 202 & 0.553 & 3.0 & 11 & 0.030 & 0.2 \\
\hline Cardboard (and paper) & 529 & 1.449 & 8.0 & 349 & 0.956 & 6.1 \\
\hline Other paper & 974 & 2.668 & 14.7 & 179 & 0.490 & 3.1 \\
\hline Food and vegetation waste & 609 & 1.668 & 9.2 & 418 & 1.145 & 7.3 \\
\hline Textiles & 95 & 0.260 & 1.4 & 25 & 0.068 & 0.4 \\
\hline Glass & 37 & 0.101 & 0.6 & 40 & 0.110 & 0.7 \\
\hline Rubber & 4 & 0.011 & 0.1 & 4 & 0.011 & 0.1 \\
\hline Polystyrene & 21 & 0.058 & 0.3 & 9 & 0.025 & 0.2 \\
\hline Scrap wood & 1076 & 2.948 & 16.2 & 4151 & 11.373 & 72.1 \\
\hline Sewage sludge & 688 & 1.885 & 10.4 & 70 & 1.885 & 1.2 \\
\hline Ashes & 811 & 2.222 & 12.2 & 0 & 2.222 & 0.0 \\
\hline Miscellaneous & 838 & 2.296 & 12.6 & 52 & 2.296 & 0.9 \\
\hline Total & $6628:: 6627$ & $\mathbf{3 6 . 3}$ & 100 & 5756 & $\mathbf{1 5 . 8}$ & 100.1 \\
\hline
\end{tabular}


Table 5. Solid waste generated at the Force Providers training site.

\begin{tabular}{|l|c|}
\hline Component & Ib/(person-day) \\
\hline Trash and kitchen waste (minus slop food) & 3.2 \\
\hline Slop food & 0.7 \\
\hline Cooking oil & 0.2 \\
\hline Total & 4.3 \\
\hline
\end{tabular}

\subsubsection{Camp Atterbury, IN}

Camp Atterbury, IN is a National Guard installation that has established three training FOBs in recent years (developed by the 205th Infantry Brigade, LTC CraigJ ohnson, Battalion Commander). These three sites were developed to host soldiers from several other CONUS installations for their required pre-deployment training. These training missions are designed to familiarize outgoing soldiers with in-theater living conditions, security procedures, etc. The training realism is thought to be fairly good. Soldiers live in trailers (Figure 2), shower in trailers, use portable toilets, dine in the dining facility (DFAC), etc.

FOB 3 is especially attractive for these utility studies because power and water are metered separately from the rest of the installation. Also, the DPW oversees solid waste and septage hauling contracts.

Table 6 lists recent solid waste generation figures.

\subsubsection{Camp Shelby, MS}

Camp Shelby is a National Guard installation near Hattiesburg, MS. Like Camp Atterbury, it hosts a busy pre-deployment training schedule. There are four training Contingency Operating Locations (COLs), a term synonymous with FOB. CERL researchers visited the site in September 2010 to collect utility usage data, and attempt to correlate that with COL population. Figure 3 shows COL 4, the largest with a capacity of 1434 soldiers, roughly half in tents and half in containerized housing units (CHUs). 


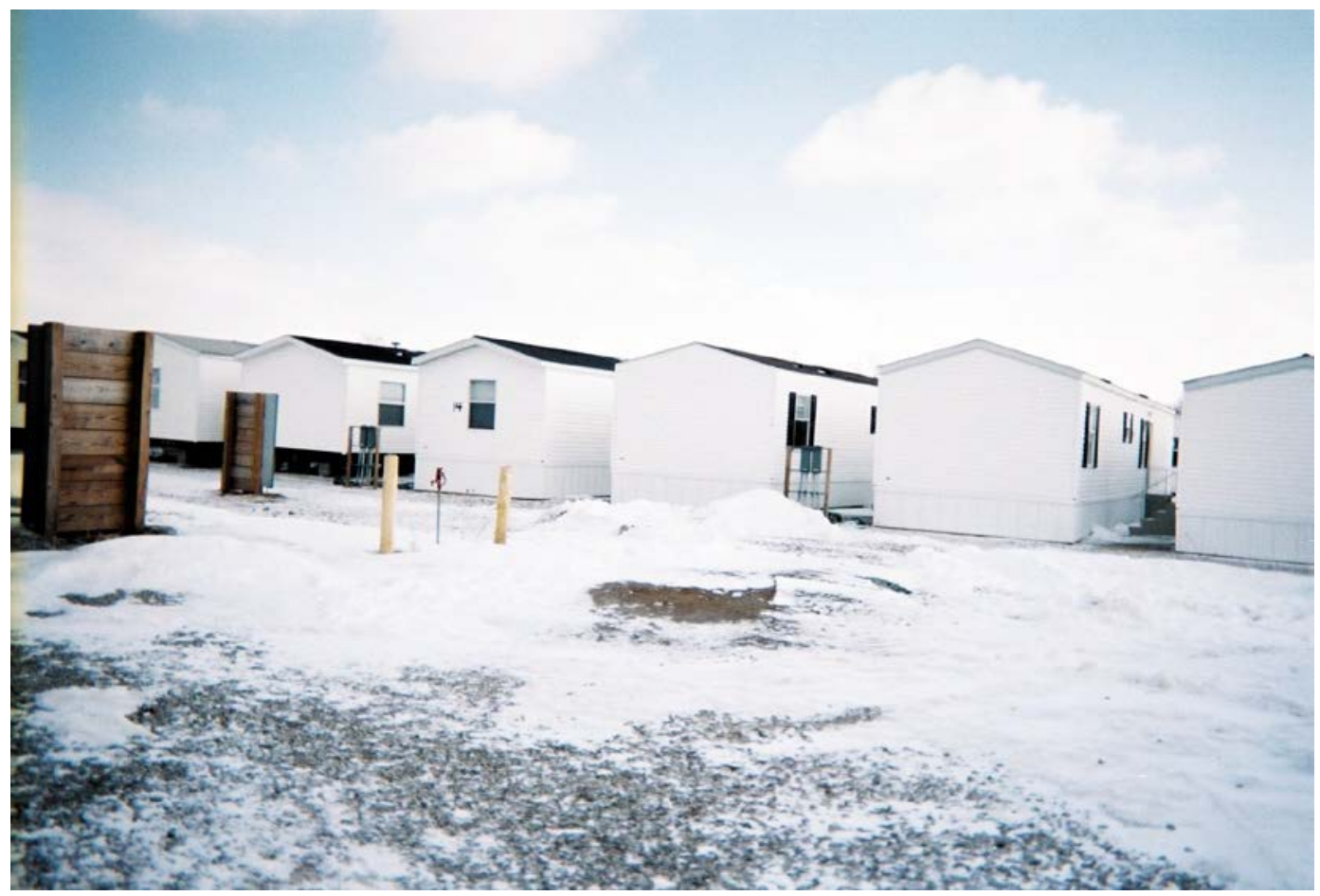

Figure 2. Barracks at Camp Atterbury, FOB 3.

Table 6. Solid waste generation at Camp Atterbury, FOB 3.

\begin{tabular}{|l|c|c|c|c|r|r|r|r|r|}
\hline Unit & Jun 2009 & Jul 2009 & Aug 2009 & Sep 2009 & Oct 2009 & Nov 2009 & Dec 2009 & Jan 2010 & Avg \\
\hline PAX. & 620 & 1120 & 570 & 640 & 730 & 350 & 225 & 180 & 554 \\
\hline cu yd/month & 144 & 112 & 80 & 144 & 96 & 56 & 48 & 136 & 102 \\
\hline Ib/month & 32,400 & 25,200 & 18,000 & 32,400 & 21,600 & 12,600 & 10,800 & 30,600 & 22,950 \\
\hline Ib/(PAX-day) & 1.74 & 0.75 & 1.05 & 1.69 & 0.99 & 1.20 & 1.60 & 5.67 & 1.84 \\
\hline
\end{tabular}

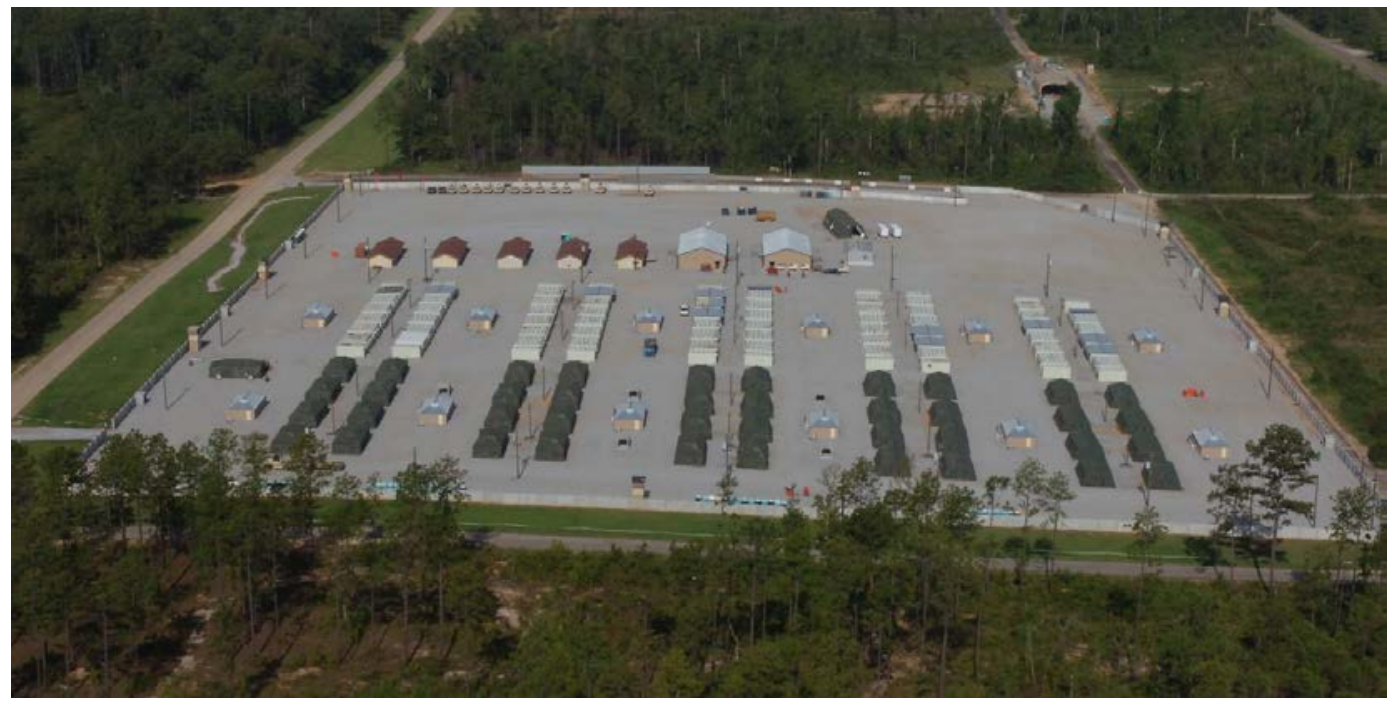

Figure 3. COL 4 at Camp Shelby. 


\subsubsection{Afghanistan}

In J anuary 2011, a CERL researcher who is an Army Reserve Engineer Officer traveled to Afghanistan and visited four contingency base camps: New Kabul Compound, Camp Phoenix, FOB Salerno, and Camp Leatherneck. The researcher conducted interviews with base camp mayor staffs and contract support personnel, and made observations on solid waste management operations. However, no formal data was collected from the waste streams.

\subsubsection{Camp Phoenix and New Kabul Compound}

Camp Phoenix and the New Kabul Compound are urban base camps that are part of the Kabul Base Cluster. Solid waste at both these facilities is collected by a contractor and hauled off base for disposal. Any type of onsite burning (open pit or incinerator) is not feasible due to the lack of space and the overall poor air quality in the Kabul metropolitan area. Both facilities have made a good effort to segregate waste streams and recycle when feasible. No data were available on daily waste generation rates. Figures 4 and 5 shows the solid waste collection at Camp Phoenix and the New Kabul Compound, respectively. Figures 6 and 7 show New Kabul Compound recycling bins and battery disposal.

\subsubsection{FOB Salerno}

FOB Salerno is a remote base camp located near the Pakistani border that has an approximate population of 5600. Solid waste at the site was collected in contractor furnished disposal bins and hauled by the contractor to their burn pit. Soldiers were generally not involved in the collection and disposal process. The Logistics Civil Augmentation Program (LOGCAP) contractor estimated an average disposal volume of $250 \mathrm{~m} 3 /$ day, which is equivalent to $13.1 \mathrm{lb} /$ person/ day. All incoming loads were dumped into a holding area for inspection and segregation. Waste streams went to several locations in the facility. Usable military materiel was set aside for later reuse. Non-burnable scrap such as metal was stockpiled for later recycling. Wet DFAC waste was put into an open pit to be burned using scrap wood for combustion. All plastics were removed from the waste stream and stockpiled in a large pit. Because the base was remote, there was no market for plastic recycling; as a result, the site had accumulated a large quantity of plastic bottles that could not be properly disposed of. Finally, combustible solid waste was burned in an air-curtain burn box. 


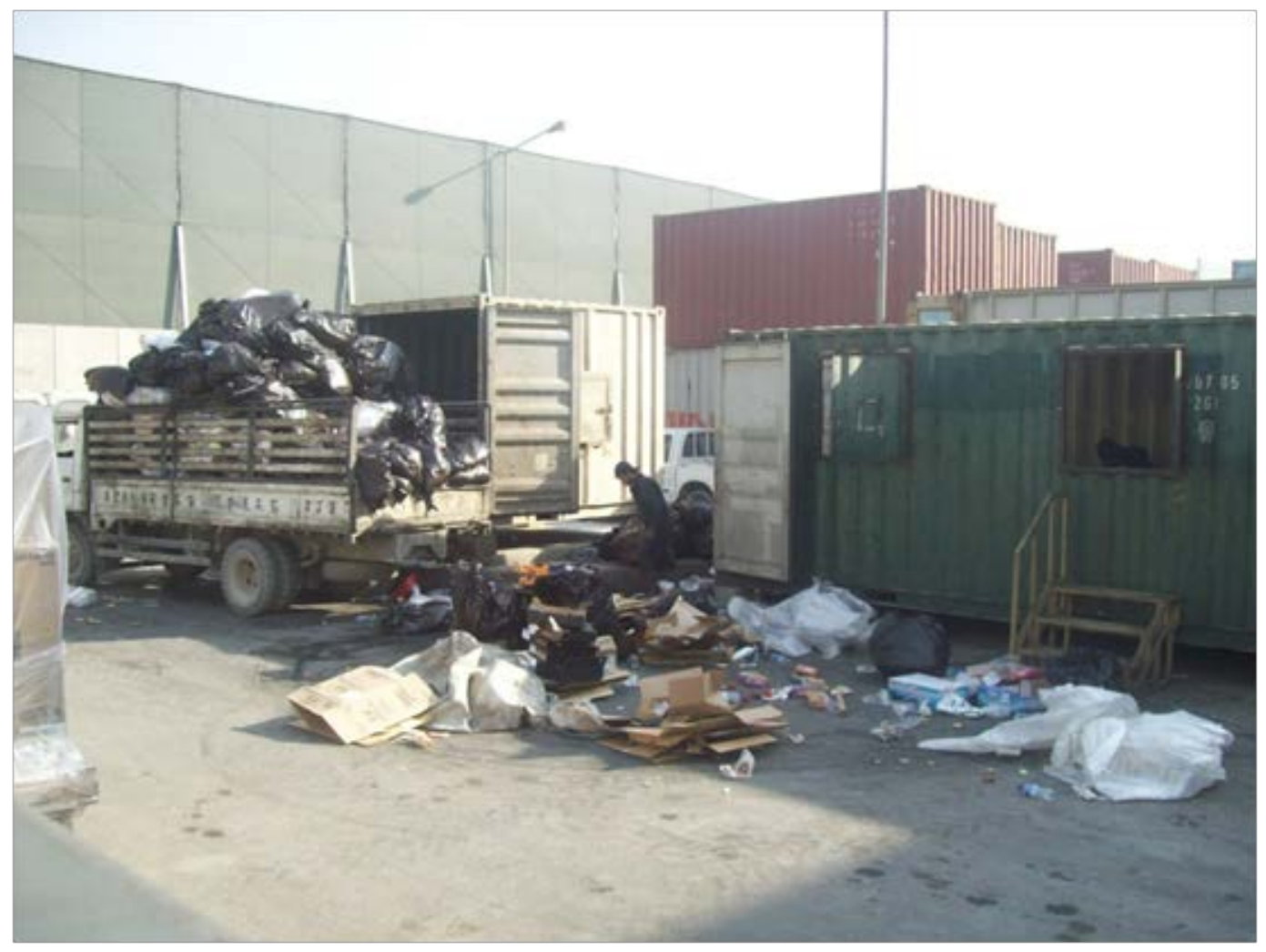

Figure 4. Solid waste collection at Camp Phoenix.

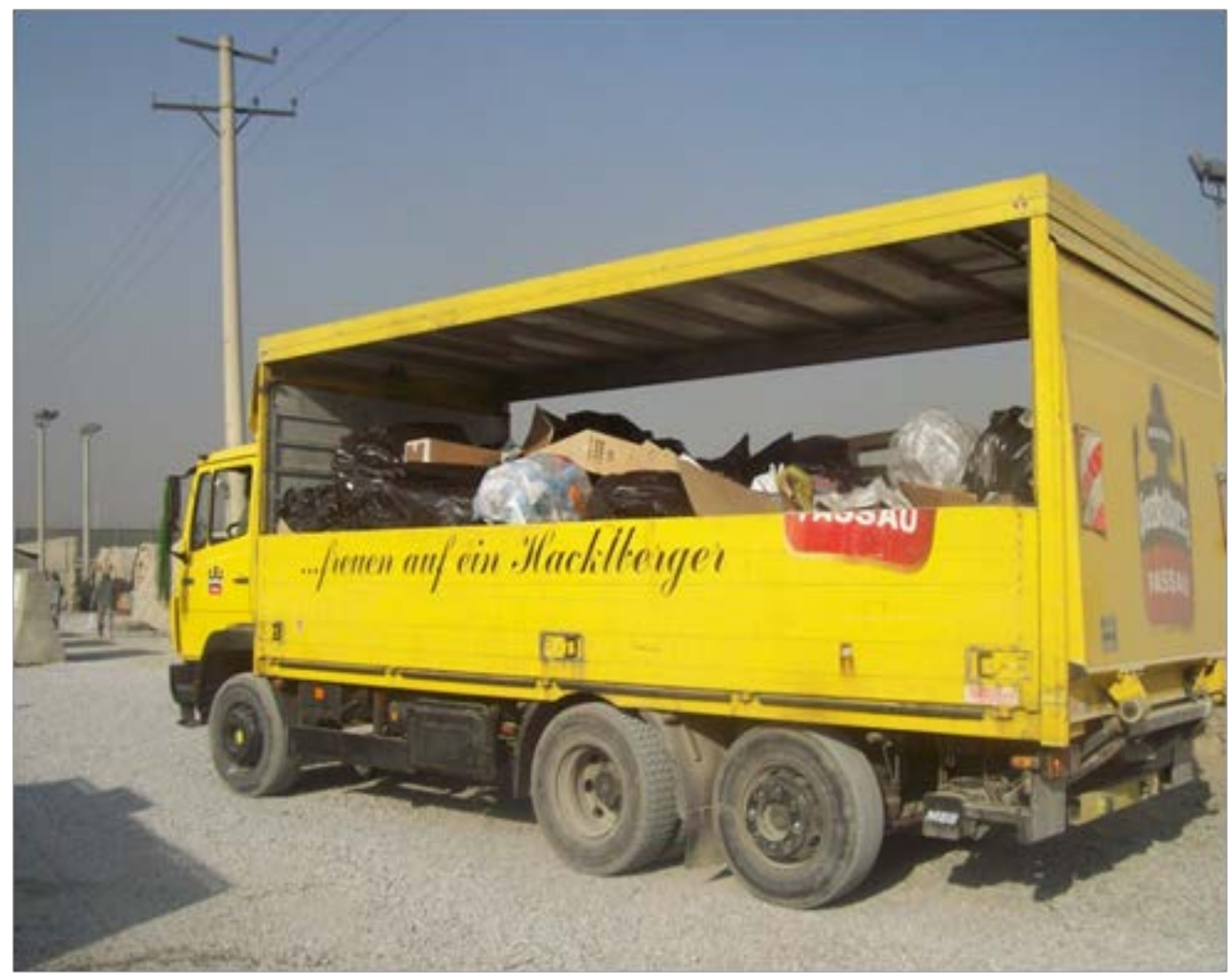

Figure 5. Solid waste collection at New Kabul compound. 


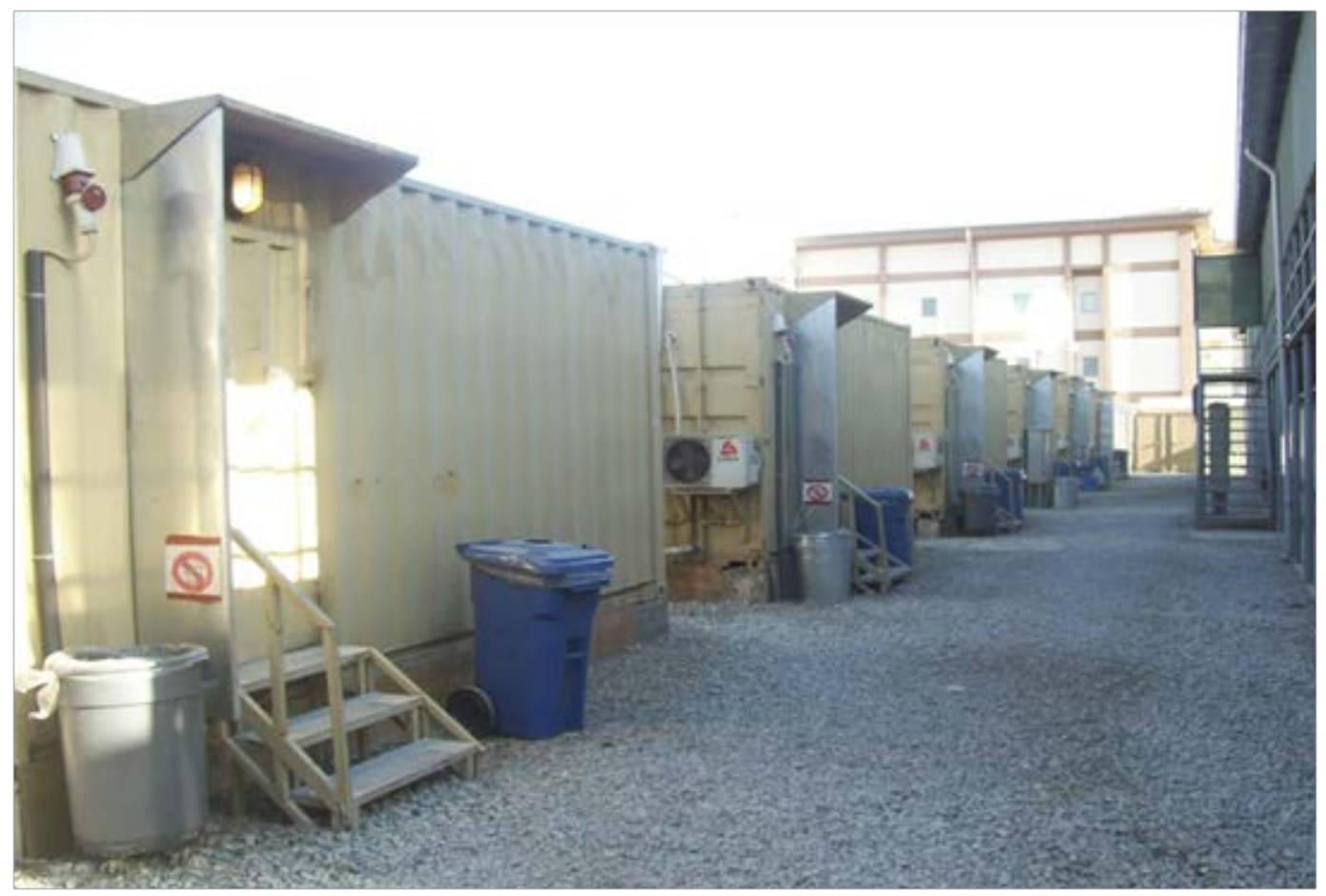

Figure 6. Recycling bins at New Kabul Compound.

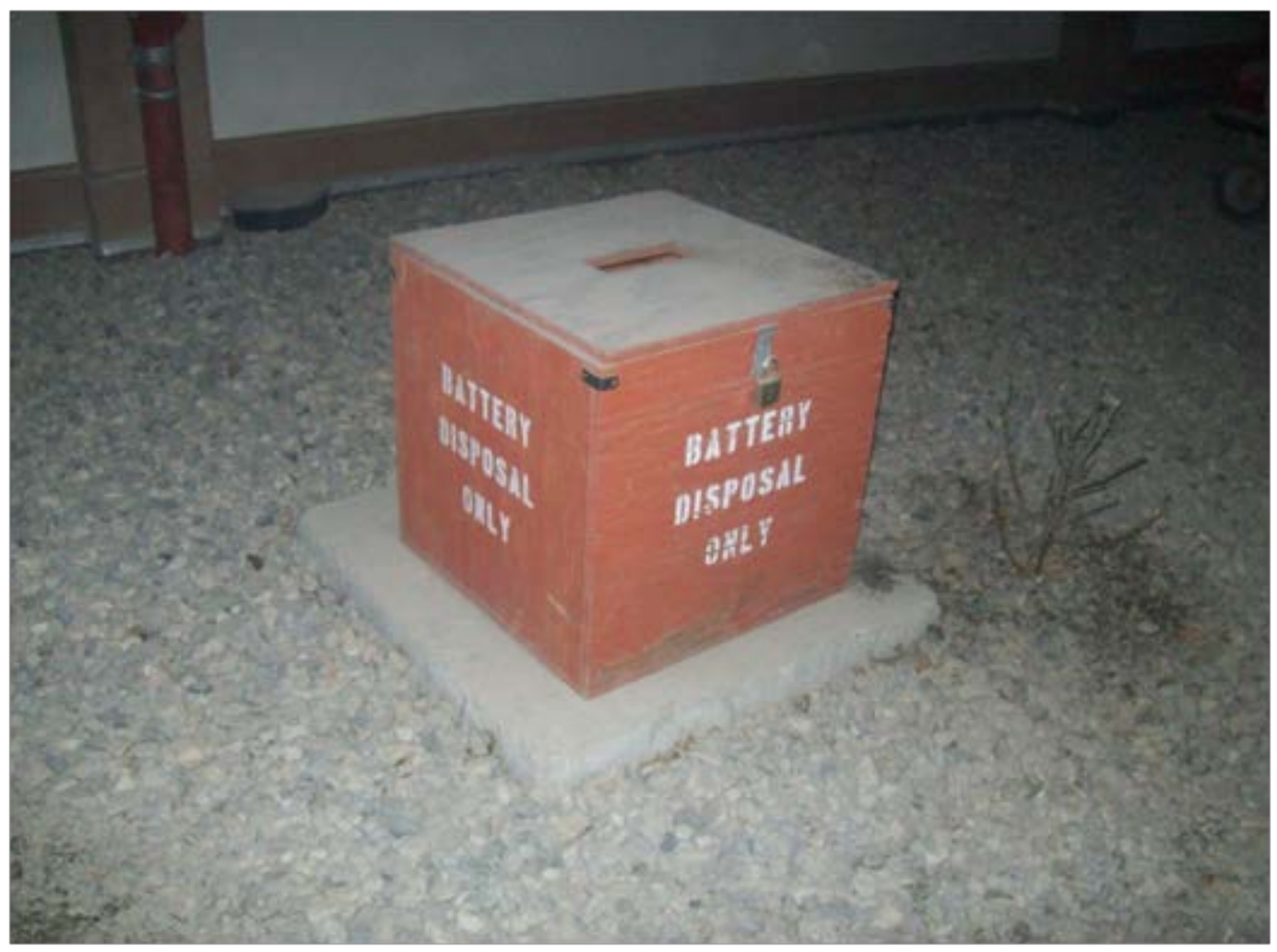

Figure 7. Battery disposal at New Kabul Compound. 
The average disposal volume at FOB Salerno of $13.1 \mathrm{lb} /$ person/ day is slightly lower than the recommended planning factor. Although there was a moderate amount of construction at this base, most was done using locally manufactured brick and cast concrete, which generates very little construction debris requiring disposal. Also at the time of the visit, there was little turnover of base units and personnel, which significantly decreased the amount of waste packing and shipping materials. Figure 8 shows solid waste disposal operations at FOB Salerno; Figure 9 shows a burn box and residual ash; Figure 10 shows waste segregation, and Figure 11 shows stockpiled plastic waste.

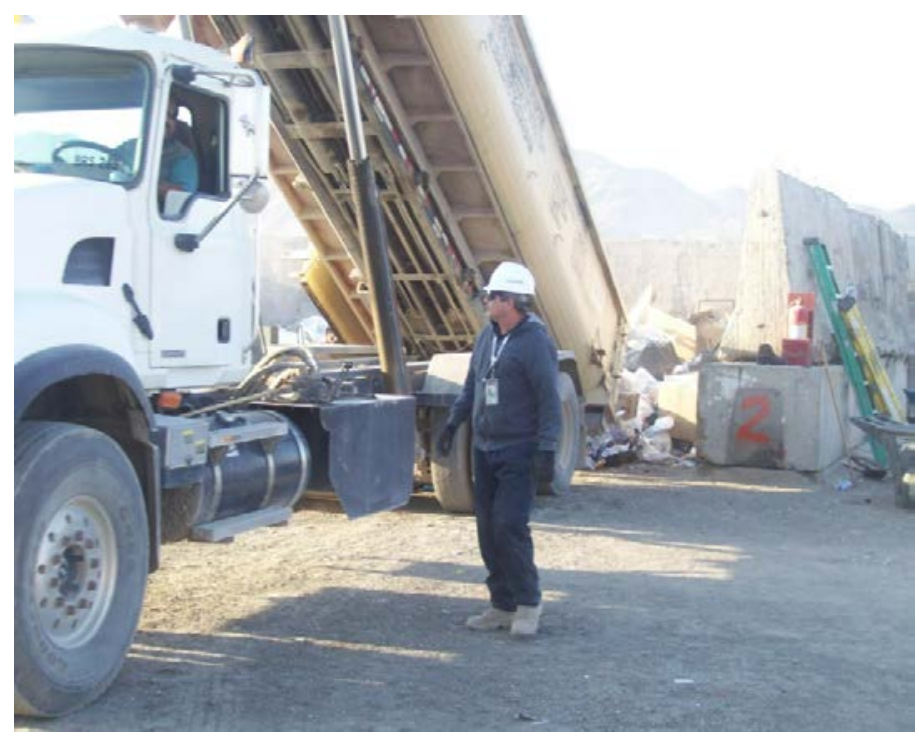

Figure 8. Salerno solid waste disposal operations.

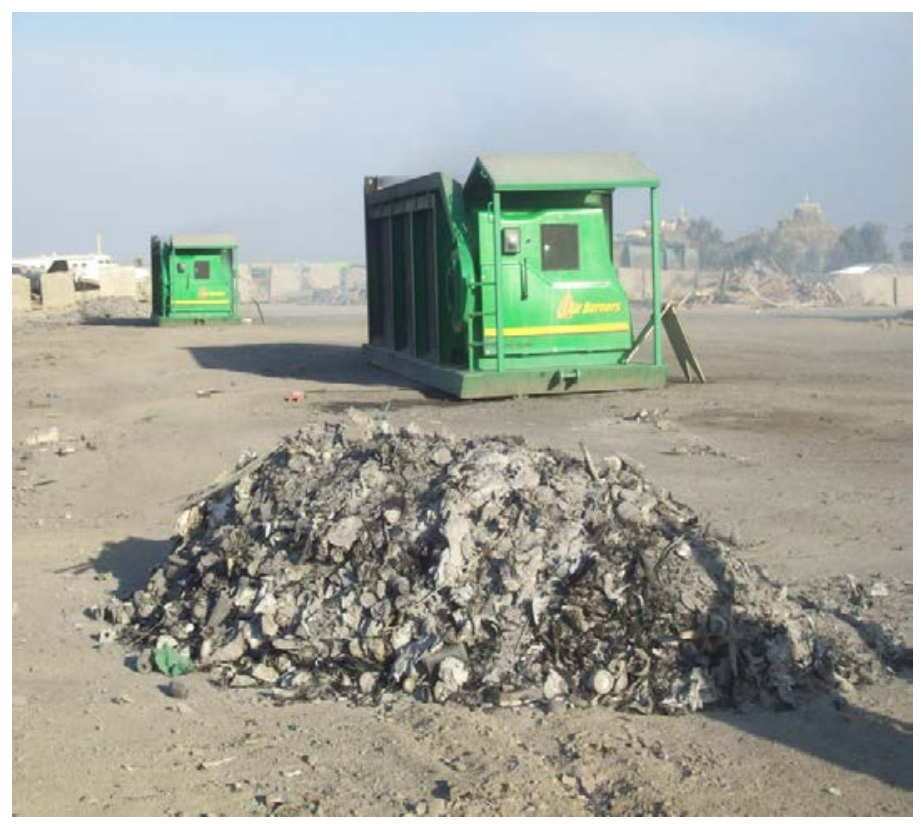

Figure 9. Burn box and residual ash. 


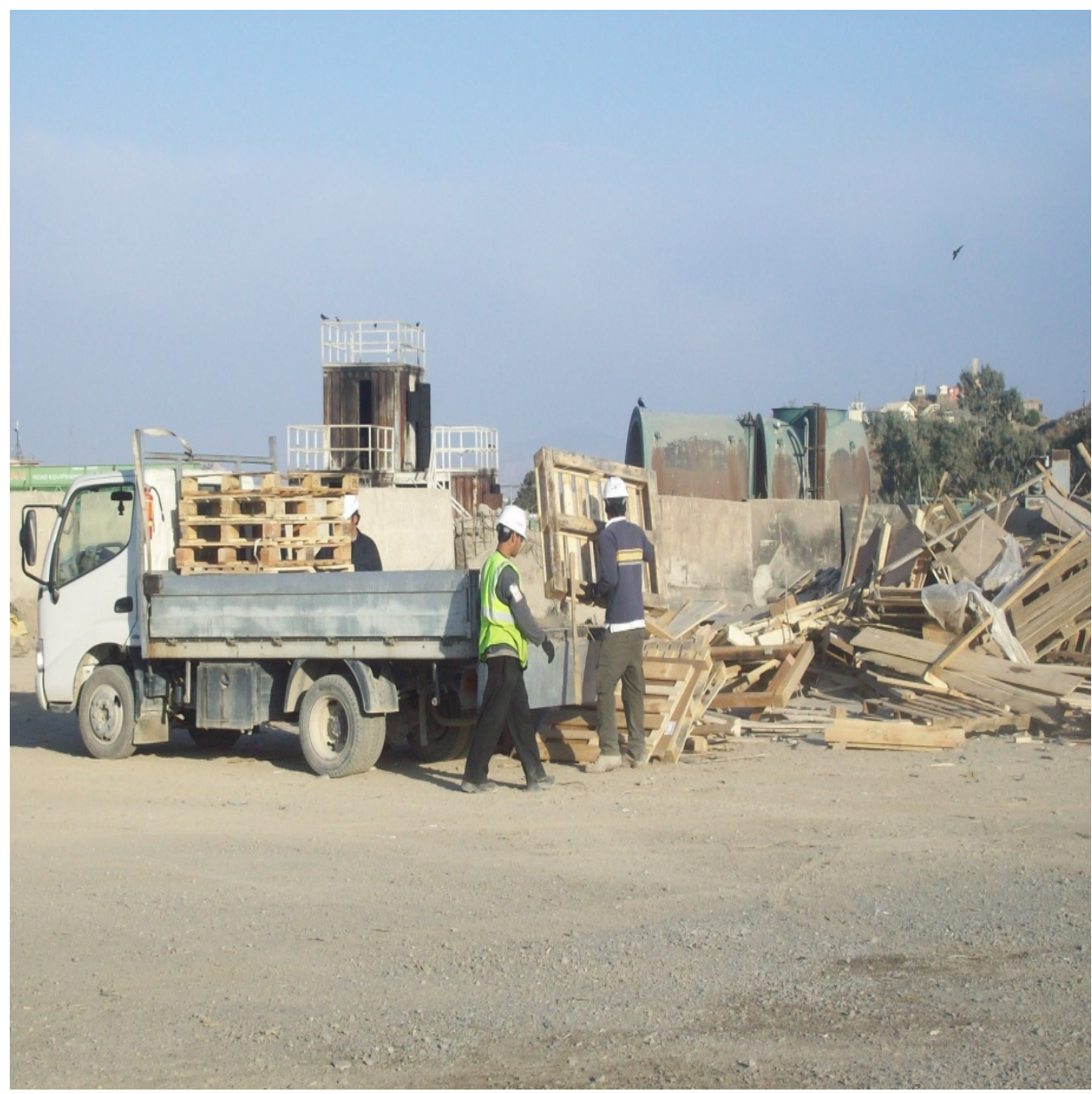

Figure 10. Salerno waste segregation.

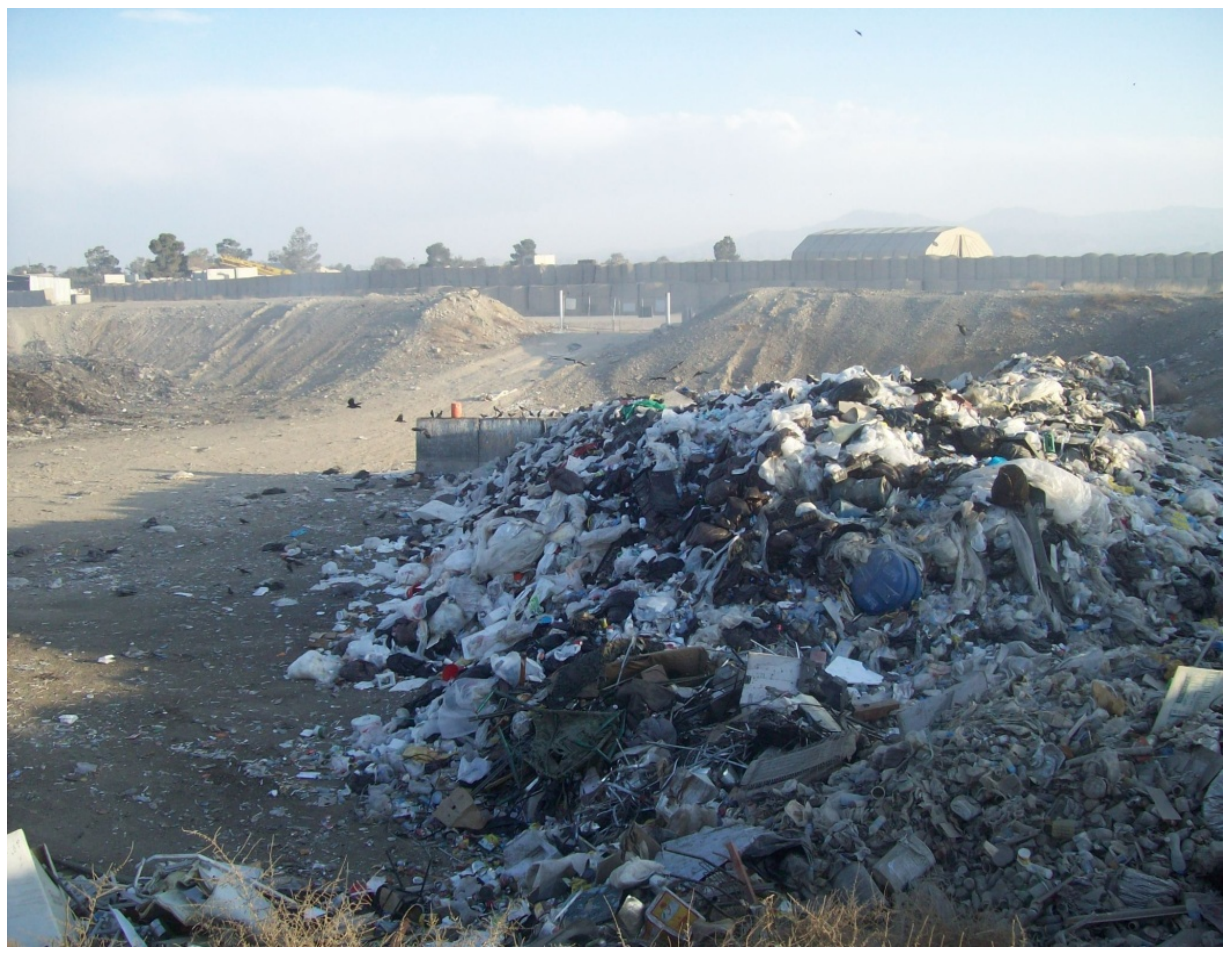

Figure 11. Stockpiled plastic waste at Salerno. 


\subsubsection{Camp Leatherneck}

Camp Leatherneck is a large Marine Corps base in southwestern Afghanistan that has an estimated population of 20,000. Solid waste at Camp Leatherneck was collected by both contractors and troop units, and was delivered to a contractor-operated burn pit. Incoming loads were inspected and logged by contractors and directed to a specific area of the burn pit operation. Non-burnable materials and plastics were segregated and stockpiled for recycling or landfilling. Combustible materials were piled in the burn area where active burning operations were conducted by trained contractor personnel. A LOGCAP contractor report estimated processing $300,000 \mathrm{lb} /$ day ( $15 \mathrm{lb} /$ person/ day). This base camp has a solid waste incinerator that was nearing completion at the time of the visit.

The solid waste generation rate of $15 \mathrm{lb} /$ person/ day validates the recommended planning factor of $15.9 \mathrm{lb} /$ person/ day. Because of the high levels of new conventional construction and unit turnover, construction debris and packing/ shipping materials volume were substantial. Figure 12 shows load inspection at Camp Leatherneck; Figure 13 shows waste segregation; Figures 14 and 15 show active burn operations; and Figures 16 and 17 show an incinerator under construction.

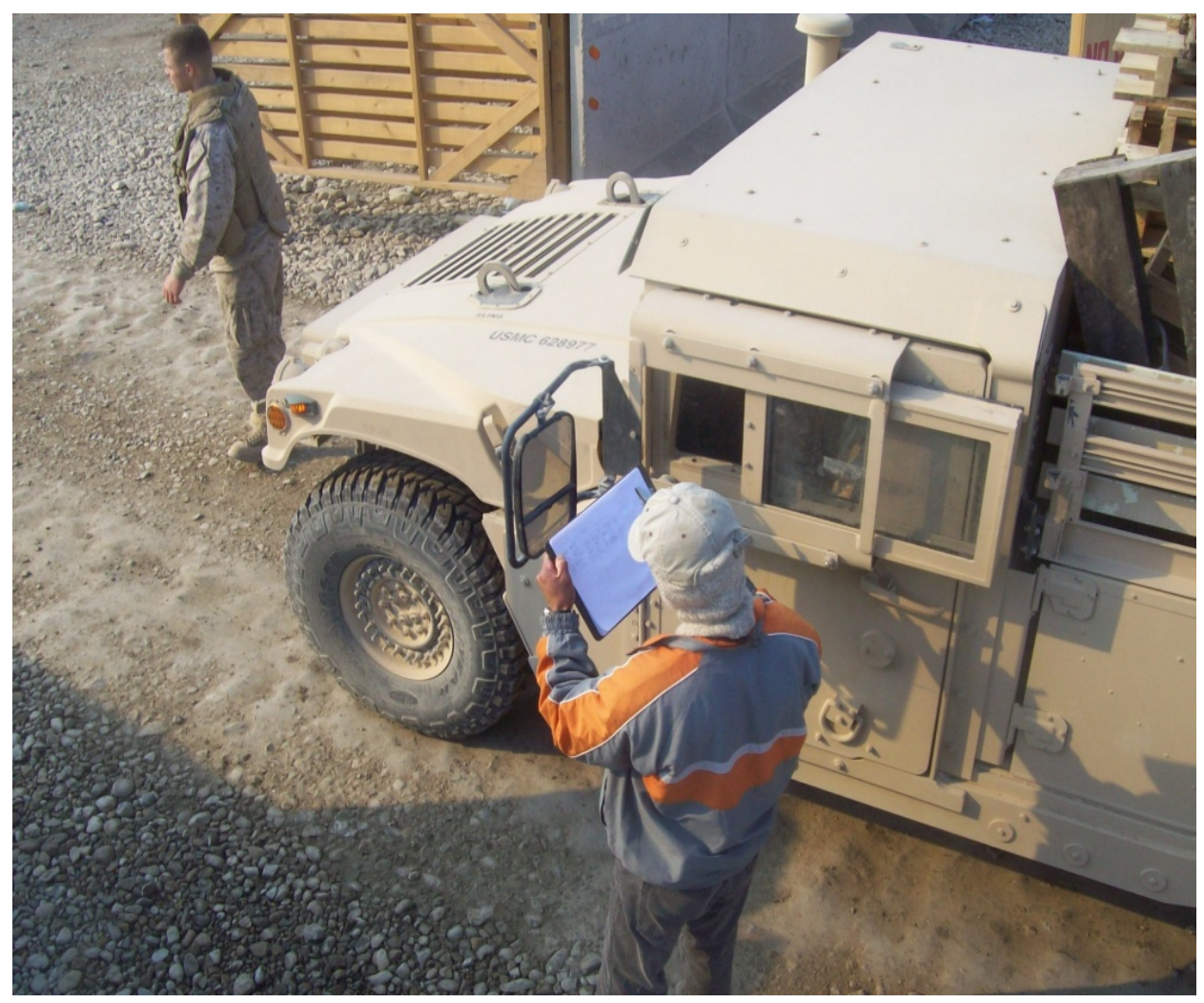

Figure 12. Load inspection at Camp Leatherneck. 


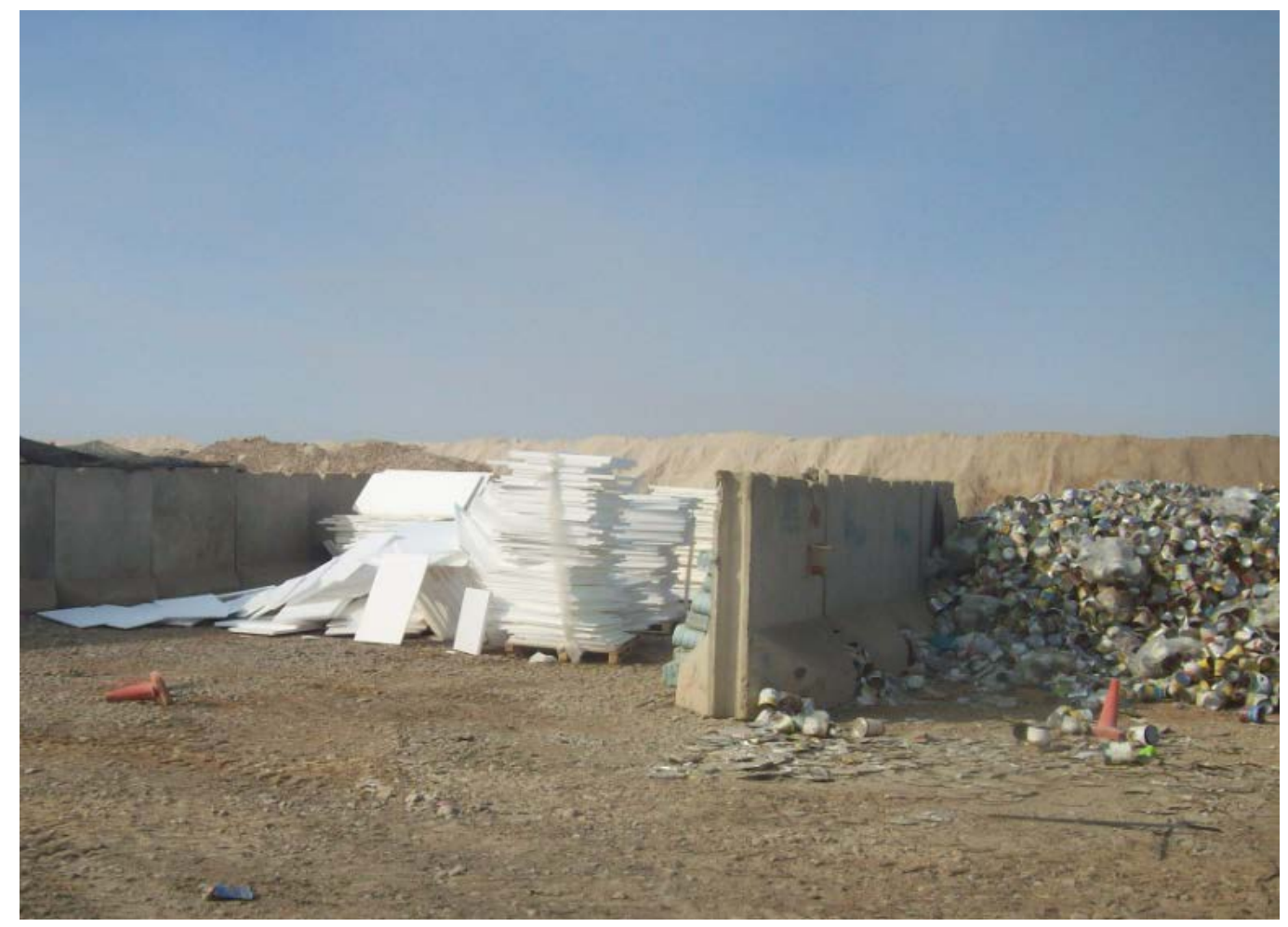

Figure 13. Waste segregation at Camp Leatherneck.

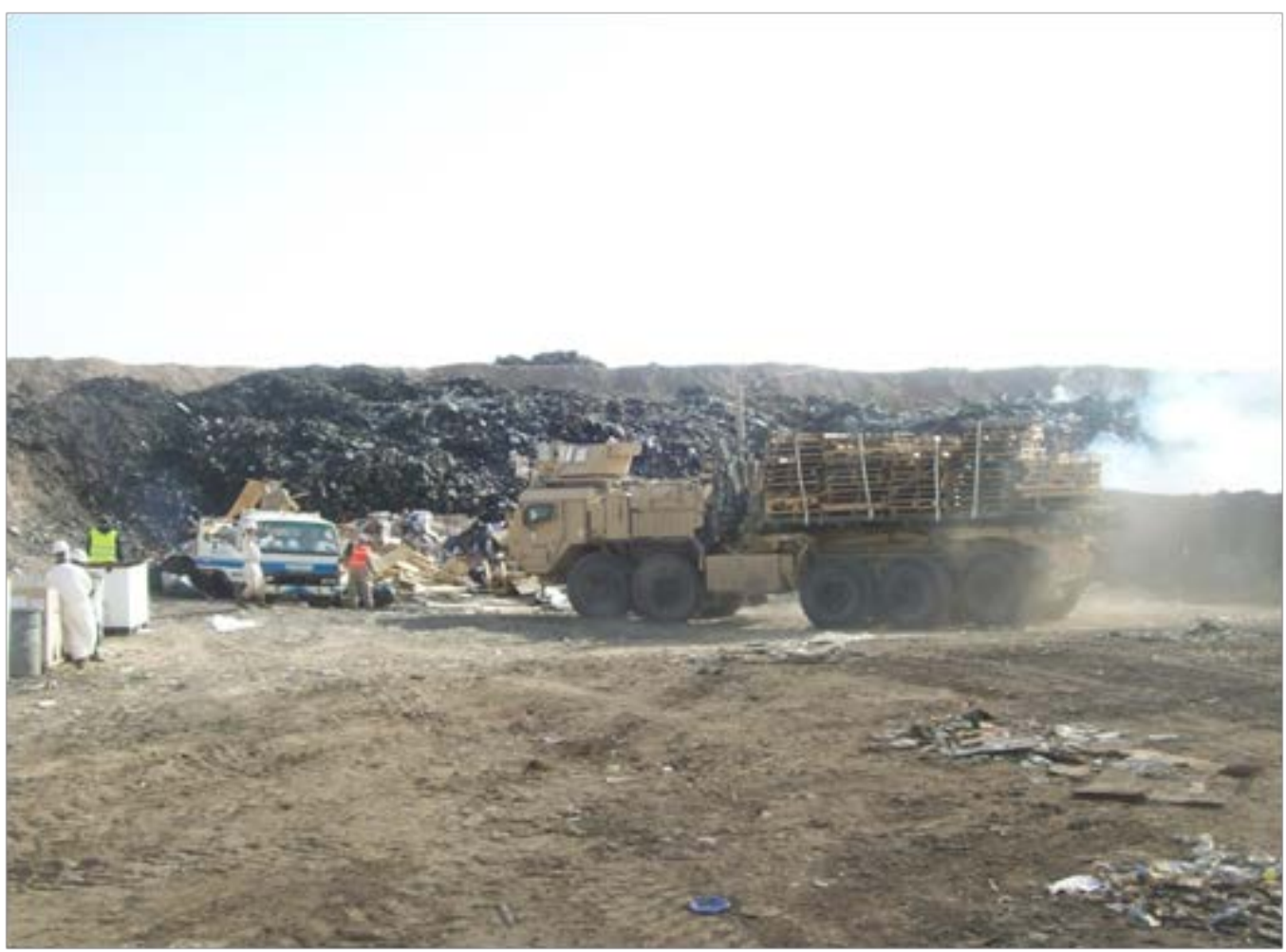

Figure 14. Camp Leatherneck active burn operation. 


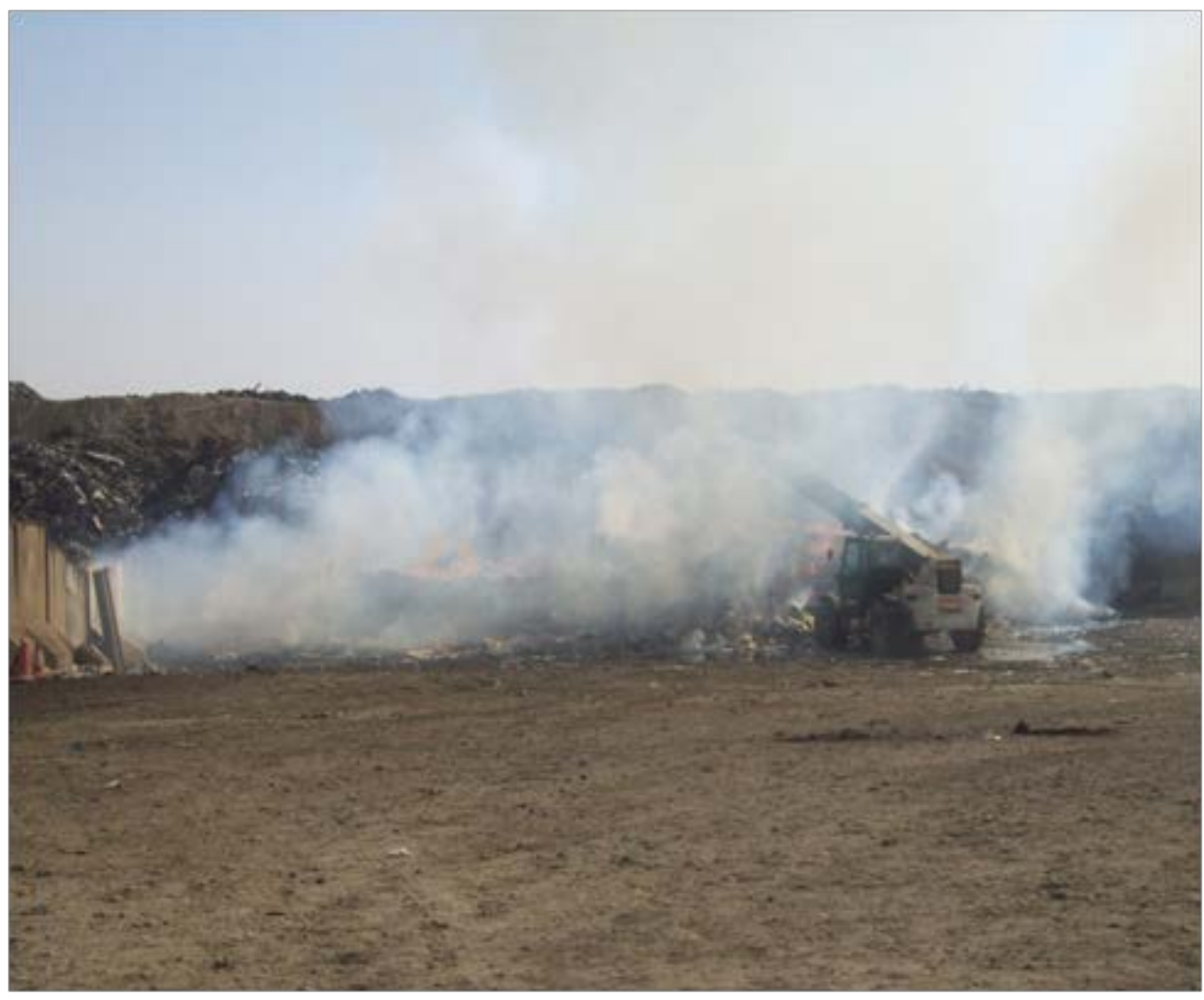

Figure 15. Another view of active burn operation at Camp Leatherneck.

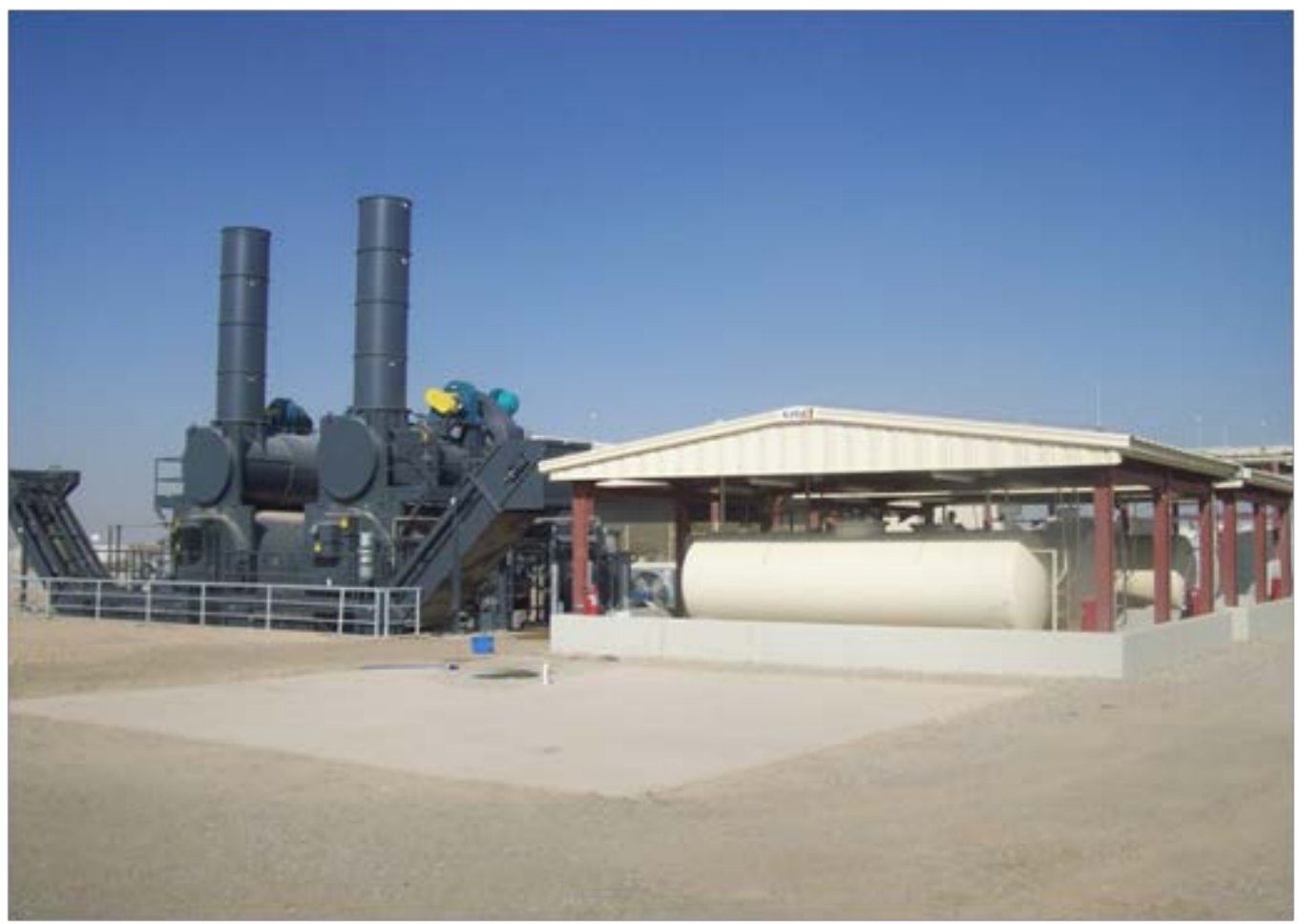

Figure 16. Incinerator under construction at Camp Leatherneck. 


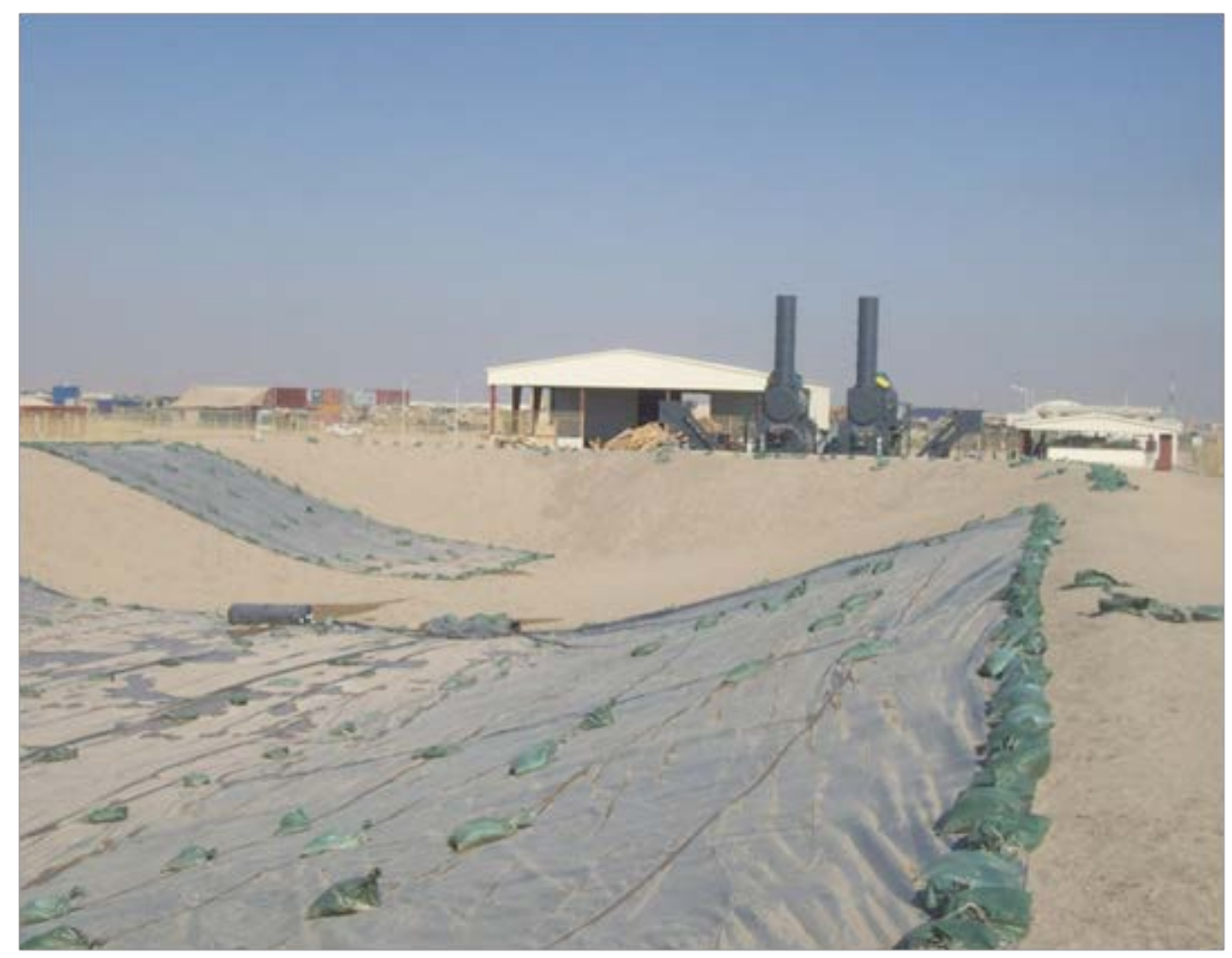

Figure 17. Another view of incinerator construction at Camp Leatherneck.

\subsection{Comparison of Solid Waste Generation Rates}

The data in Table 7 provide a basis to compare solid waste generation rates reported in detailed base camp studies in the Balkans, with observations and data from CONUS training base camps, and with observations from two base camps in Afghanistan.

CONUS training base camps best fit the characteristics of the GSTM 3.34.56 "on the move" category based on the expected types of solid waste generated. Training units arrive at these locations with little more than personnel and a small number of vehicles. They typically do not engage in any activities that generate large volumes of solid waste such as major construction or receiving shipments of supplies and equipment. The bulk of solid waste is generated from the DFAC and other Class I products such as "meals ready to eat" (MREs) or bottled water. This nearly replicates the types of waste a military unit might generate during austere initial operations, before a fixed base camp location is developed.

Observations from base camps in Afghanistan generally validate solid waste generation numbers from previous studies. Rates in theater can vary based on the mission, population, maturity of the base camp, and level of and type of construction activities. 
Table 7. Solid waste generation rates.

\begin{tabular}{|c|c|}
\hline Planning Factors & Ib/person/day \\
\hline Report recommendations & 15.9 \\
\hline GSTM 3-34.56 (base camp) & 18.2 \\
\hline GSTM 3-34.56 (“On the move”) & 4 \\
\hline Base Camp Studies & \\
\hline Camp A 2003 & 15.8 \\
\hline Camp B 2006 & 18.2 \\
\hline Force Provider & 4.3 \\
\hline CONUS Base Camp Observations & \\
\hline Camp Atterbury & 1.4 \\
\hline Camp Shelby COL 1 & 1.8 \\
\hline Camp Shelby COL 2 & 2.4 \\
\hline Camp Shelby COL 3 & 1.6 \\
\hline Camp Shelby COL 4 & 2.6 \\
\hline $\begin{array}{l}\text { Operation Enduring Freedom (OEF) } \\
\text { Base Camp Observations }\end{array}$ \\
\hline FOB Salerno & 13.1 \\
\hline Camp Leatherneck & 15 \\
\hline
\end{tabular}




\section{Blackwater Generation}

Septage or "blackwater" is latrine wastewater, including waste from flush toilets, septic tanks, port-a-johns, etc. Note that the term "septage" does not include "graywater," which is wastewater from shower, sinks, or vehicle washing.

\subsection{General}

To determine requirements for septage handling, it is reasonable to start with the basics of human biology, i.e., there is a relatively consistent quantity of wastes that the human body excretes (excreta or night soil). Once those figures are clearly understood (or understand within a reasonable range), adjustments to those numbers are simply based on the dilution of the particular toilet technology employed. For example, a flush toilet dilutes the basic excreta to a far greater extent than does a chemical toilet.

The amount of human excreta varies widely depending on diet, water consumption, age (of the person), climate (temperature and humidity), and life (exercise) pattern. A Guide to the Development of On-Site Sanitation, published by the World Health Organization (WHO 1992) recommends that, in the absence of local information, the following figures be used as reasonable averages:

- high-protein diet in a temperate climate: $0.12 \mathrm{~kg} / \mathrm{person} /$ day feces (wet mass), and $1.2 \mathrm{~L} /$ person/ day urine

- vegetarian diet in a tropical climate: $0.40 \mathrm{~kg} /$ person/ day feces (wet mass) and $1.0 \mathrm{~L} /$ person/ day urine.

The Composting Toilet System Book (Del Porto and Steinfeld 1999) reported: $0.15 \mathrm{~kg} /$ person/ day feces (wet mass) and $1.5 \mathrm{~L} /$ person/ day urine as average generation volumes for composting toilet design criteria in Europe and North America.

Considering that soldiers are young, energetic, and have a high-protein diet, generation volumes of $0.15 \mathrm{~kg} /$ person/ day feces (wet mass) and 1.5 $\mathrm{L} /$ person/ day urine appear to be reasonable. Factors affecting extra trash and water volume will differ depending on the purpose, duration, and level of forward camps. 
Assuming two flushes per capita per day for feces, and four (urinal) flushes per capita per day for urine (a very crude assumption), would yield 8 gal (30 L) to be added to the night-soil amount, which amounts to about 20 times dilution.

Finally, toilet tissues and other miscellaneous toilet disposal would be expected to increase night soil volume.

\subsection{Camp Atterbury}

Figure 18 shows toilets and wash station at FOB 3. Table 8 lists septage hauling at FOB 3.

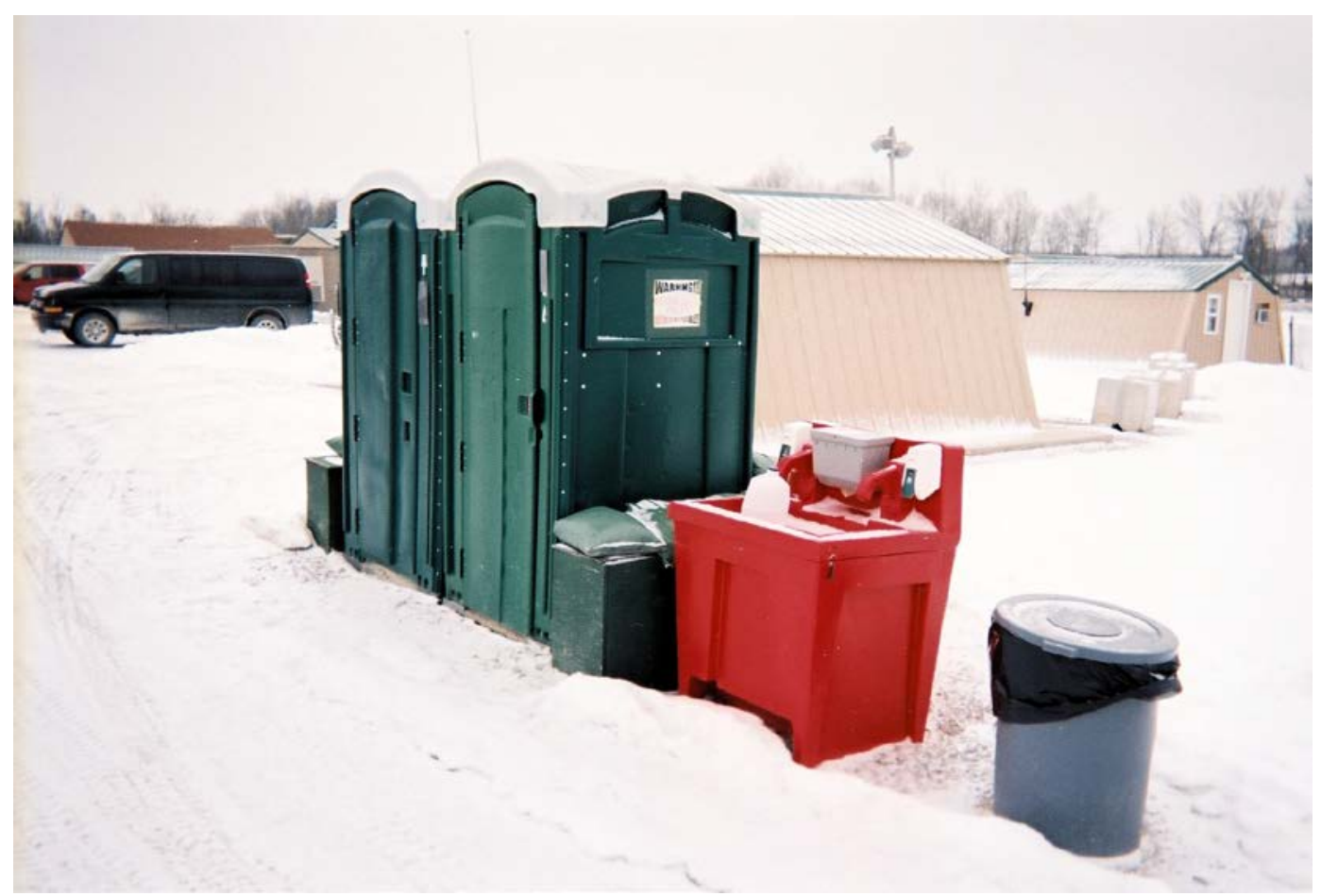

Figure 18. Toilets and wash station at FOB 3.

Table 8. Septage hauling, FOB 3.

\begin{tabular}{|l|c|c|c|c|c|c|c|c|c|}
\hline Unit & Jun-09 & Jul-09 & Aug-09 & Sep-09 & Oct-09 & Nov-09 & Dec-09 & Jan-10 & Avg \\
\hline Person & 620 & 1120 & 570 & 640 & 730 & 350 & 225 & 180 & 554 \\
\hline gal & 6750 & 6750 & 6750 & 6750 & 6750 & 6750 & 6750 & 6750 & 6750 \\
\hline gal/person-day & 0.36 & 0.20 & 0.39 & 0.35 & 0.31 & 0.64 & 1.00 & 1.25 & 0.56 \\
\hline
\end{tabular}




\section{Conclusion}

This work was an initial step in an overall effort to improve utility and sustainment protocols at Contingency Base Camps. Specifically, this work characterized and quantified solid waste generation, which includes solid waste (i.e., "trash") and septage ("blackwater") generation, "per soldier" and at the base camp level.

\subsection{Solid waste}

While FM 3-34-5 contains no information regarding generation rates of wastes, Army guidance expressed in GSTM 3-34.56 does provide quantified planning information pertaining to solid waste management at future base camps:

- "A soldier in the field can generate 20 pounds of solid waste and 80 pounds of liquid waste per day."

- "A base camp population of 2,500 can produce approximately 5,500 cubic meters, or 1,500 tons, of compostable solid waste (SW) (including sewage sludge) per year.

- "For units on the move or not situated in a base camp, planners use a generation rate of 4 pounds per person per day as a general rule of thumb.

Field studies done in the Balkans, at CONUS training base camps, and in Afghanistan confirm that, while rates in theater can vary based on the mission, population, maturity of the base camp, and level of and type of construction activities validate the solid waste generation rates given in GSTM 3-34.56.

\subsection{Septage}

Actual quantities of septage to be handled depends on the amounts of feces (wet mass) and urine produced daily, combined with water added during toilet flushes. Literature on the subject of site sanitation, and data from one site study indicate that daily, per-person septage rates range from 0.12- $0.4 \mathrm{~kg}$ feces and 1.0-1.5 L urine, which, combined with toilet flush dilution would yield up to $8 \mathrm{gal}$ of septage/ person/ day. 


\section{Acronyms and Abbreviations}

\begin{tabular}{|c|c|}
\hline Term & Definition \\
\hline AOR & Area of Responsibility \\
\hline APG & Aberdeen Proving Ground \\
\hline CALL & Center for Army Lessons Learned \\
\hline CEERD & US Army Corps of Engineers, Engineer Research and Development Center \\
\hline CERL & Construction Engineering Research Laboratory \\
\hline $\mathrm{CHU}$ & Containerized Housing Unit \\
\hline $\mathrm{COL}$ & Contingency Operating Location \\
\hline CONUS & Continental United States \\
\hline COR & Contract Officer Representative \\
\hline DFAC & Dining facility \\
\hline DOD & US Department of Defense \\
\hline DPW & Directorate of Public Works \\
\hline ERDC & Engineer Research and Development Center \\
\hline EXORD & Execution Order \\
\hline FOB & forward operating base \\
\hline FOUO & For Official Use Only \\
\hline GSTM & General Subject Technical Manual \\
\hline HQDA & Headquarters, Department of the Army \\
\hline HQUSACE & Headquarters, US Army Corps of Engineers \\
\hline ICDT & Integrated Capabilities Development Team \\
\hline LMI & Logistics Management Institute \\
\hline LOGCAP & Logistics Civil Augmentation Program \\
\hline MANSCEN & US Army Maneuver Support Center \\
\hline MHG & Marine Headquarters Group \\
\hline MOP & Manual of Practice \\
\hline MRE & Meal Ready to Eat \\
\hline NAVICP & Naval Inventory Control Point \\
\hline NAVSUP & Naval Supply Systems Command \\
\hline NCOIC & Non-Commissioned Officer in Charge \\
\hline $\mathrm{OEF}$ & Operation Enduring Freedom \\
\hline OMB & Office of Management and Budget \\
\hline PAX & Total Personnel \\
\hline PWTB & Public Works Technical Bulletin \\
\hline RDECOM & Research, Development, and Engineering Command \\
\hline SAR & Same As Report \\
\hline SF & standard form \\
\hline SW & Solid Waste \\
\hline TD & Temperature Drop \\
\hline
\end{tabular}




$\begin{array}{ll}\text { Term } & \text { Definition } \\ \text { TOA } & \text { Transfer of Authority } \\ \text { TR } & \text { Technical Report } \\ \text { TRADOC } & \text { US Army Training and Doctrine Command } \\ \text { US } & \text { United States } \\ \text { USAAA } & \text { US Army Audit Agency } \\ \text { USACE } & \text { US Army Corps of Engineers } \\ \text { USACHPPM } & \text { US Army Center for Health Promotion and Preventive Medicine (now known } \\ \text { WEF } & \text { as the US Army Public Health command [USAPHC]) } \\ \text { WHO } & \text { Water Environment Federation } \\ \text { WWTP } & \text { World Health Organization } \\ \text { WWW } & \text { Wastewater Treatment Plant }\end{array}$




\section{References}

\section{Open Literature}

Babington, Deepa. 5 April 2010. No fries with that: Fast food axed at Afghan bases. Reuters, http://www.reuters.com/article/2010/04/05/us-afghanistan-fastfoodidUSTRE6342J720100405

Bruce, Trent MAJ . 10 J anuary 2011. Experience as DPW OIC, Kabul Base Cluster, 201011. Interview by Garth Anderson, Camp Phoenix, Afghanistan.

Connolly, Katie. 13J uly 2009. A sickening situation. Newsweek 154(2):17.

Del Porto, David, and Carol Steinfeld. 1999. The Composting Toilet System Book. Concord, MA: The Center for Ecological Pollution Prevention.

Erwin, Sandra I. April 2010. Trick questions: How much does the pentagon pay for a gallon of gas? National Defense 94(677):30-32.

Fine Maron, Dina. 13 J anuary 2010. Pentagon weighs cleanups as it plans Iraq exit. New York Times, http://www.nytimes.com/gwire/2010/01/13/13greenwire-pentagon-weighscleanups-as-it-plans-iraq-exit-21915.html?pagewanted=all

. 22 December 2009. Pentagon shifts stance on burn pits, acknowledges health effects. Greenwire. Washington, DC: E\&E Publishing, LLC, http://www.eenews.net/public/Greenwire/2009/12/22/2

Gerdes, Gary L., Deborah Curtin, and Christopher Gutkowski. September 2008. Hydrothermal processing of base camp solid wastes to allow onsite recycling. ERDC/ CERL TR-08-13. Champaign, IL: Engineer Research and Development Center, Construction Engineering Research Laboratory (ERDC-CERL).

Headquarters, Department of the Army (HQDA). 16 J une 2008. Army Campaign Plan 2008 Execution Order (EXORD) Washington, DC: HQDA.

—. February 2010. Environmental Considerations, Field Manual (FM) No. 334.5/ MCRP 4-11B (3-100.4). Washington, DC: HQDA.

Headquarters, US Army Corps of Engineers (HQUSACE). 1 April 2008. Solid Waste Generation Rates at Army Base Camps. Public Works Technical Bulletin (PWTB) 2001-1-51. Washington, DC: HQUSACE, http://www.wbdg.org/ccb/ARMYCOE/PWTB/pwtb_200_1_51.pdf

Kennedy, Kelly. 29 October 2008. Burn pit at Balad raises health concerns. Military Times. Springfield, VA: Gannett Government Media Corporation, http://www.militarytimes.com/news/2008/10/military_burnpit_102708w/ 24 December 2008. Report cites low health risk from burn pits. Air Force Times. Springfield, VA: Gannett Government Media Corporation. Accessed 8J anuary 2009, http://www.airforcetimes.com/news/2008/12/airforce_burnpit_122308/ 
3 October 2008. Report: Army making toxic mess in war zones. Military Times. Springfield, VA: Gannett Government Media Corporation, http://www.armytimes.com/news/2008/10/military_toxiciraq_100208w/

Lang, Mark E. 1997. Septage handling - MOP 24. Water Environment Federation (WEF) Manual of Practice (MOP). Alexandria, VA: WEF.

LaPlante, Matthew D. 15J anuary 2010. Vets: Burn pits are killing us. Salt Lake City Tribune. http://www.sltrib.com/News/ci_14182242

Marine Headquarters Group (MHG), Camp Leatherneck (Colonel J ames Flowers, RC-SW C7; Major Jim Franks, MHG XO; Captain Thano Pravong, Camp Commandant). 22 J anuary 11. Experience as MHG Camp Leatherneck, 2010-11. Interviews by Garth Anderson, Camp Leatherneck, Afghanistan.

MoCracken, Michael MAJ. 17J anuary 2011. Experience as TF Rakkasan Brigade Engineer, 2010-11. FOB Salerno, Afghanistan.

Mosher, David E., Beth E. Lachman, Michael D. Greenberg, Tiffany Nichols, Brian Rosen, and Henry Willis H. 2008. Green warriors: Army environmental considerations for contingency operations from planning through post-conflict. Santa Monica, CA: RAND Corporation, www.rand.org/pubs/monographs/MG632/

Naval Inventory Control Point (NAVICP) 077 Study Team. April 2008. Afloat solid waste characterization study. Naval Supply Systems Command (NAVSUP), http://agraconew.com/linked/nimitzreportabbrev.pdf

New Kabul Compound Mayor Cell (LTC Kirk Oldre, Mayor; SGM Terry Helget, Garrison NCOIC; MAJ Tom Krull, Deputy Garrison OIC; 1LT Margaret Bendorf, ATO; 1LT Cody Byrum, COR). 11J anuary 2011. Experiences as Mayor Cell in New Kabul Compound, 2010-11. Interview by Garth Anderson; Kabul, Afghanistan.

Ruppert, W. H., T. A. Bush, D. P. Verdonik, J . A. Geiman, and M. A. Harrison. 2004. Force provider solid waste characterization study. Natick/TR-04/017. Natick, MA: US Army Research, Development and Engineering Command, Natick Soldier Center, http://www.dtic.mil/cgi-bin/GetTRDoc?AD=ADA427565

Shane, Leo. 4 august 2009. Obama says burn pits won't become another agent orange. Stars and Stripes Online, http://www.stripes.com/news/obama-says-burn-pits-won-tbecome-another-agent-orange-1.93801

Shea, Thomas J . J uly-September 2007. Building a base camp. Engineer 37(3):12.

Wiesner, Mark LTC. 10 J anuary 2011. Experience as Base Support Group OIC (Mayor) Camp Phoenix, Afghanistan, 2010-11. Interview by Garth Anderson, Camp Phoenix, Afghanistan.

World Health Organization (WHO). 1992. A Guide to the Development of On-Site Sanitation. Geneva, Switzerland: WHO, http://whalibdoc.who.int/publications/1992/9241544430_eng.pdf 


\section{For Official Use Only (FOUO)}

Center for Army Lessons Learned (CALL). August 1999. Integrating military environmental protection. CALL Newsletter. No. 99-9. Fort Leonard Wood, MO: CALL. (FOUO)

- November 2004. Environmental considerations during military operations. CALL Newsletter. No. 04-19. Fort Leonard Wood, MO: CALL. (FOUO)

Canes, Michael E., Christopher P. Werle, MatthewW. Philipp, and Major Stacy A. Mosko. February 2004. An analysis of the energy potential of waste in the field. DRP30T1. McLean, VA: Logistics Management Institute (LMI). (FOUO)

CH2MHill. J anuary 2008. Iraq environmental conditions survey. Atlanta, GA: CH2MHill. (FOUO)

CH2MHill, Military Planning Group. March 2009. AOR Environmental Component Plan. Atlanta, GA: CH2MHill. (FOUO)

Gerdes, Gary L., and Andrew L. J antzer. September 2006. Base camp solid waste characterization study. ERDC/ CERL TR-06-24. Champaign, IL: ERDC-CERL.

J antzer, Andrew L., and Gary L. Gerdes. November 2005. Base camp utility technology matrix. ERDC/ CERL TR-05-34. Champaign, IL: ERDC-CERL. (FOUO)

Tucker, Robert E., J ames F. Lee, and William R. Gatewood. 2004.Waste management in the Balkans. File Report at Headquarters, US Army Europe, Deputy Chief of Staff, Engineer. (FOUO)

US Army Audit Agency (USAAA). 13 J anuary 2010. Army strategy for establishing, sustaining, and transitioning non-traditional installations. A-2010-0XXX-ALE (Pre-decisional). Alexandria, VA: USAAA. (FOUO)

US Army Center for Health Promotion and Preventive Medicine (USACHPPM) [now known as the US Army Public Health command [USAPHC]]. Solid waste burning (trash and feces fires) - medical. USACHPPM, Aberdeen Proving Ground (APG), MD. Fact sheet 65-035-0503. (FOUO)

USACHPPM. 2004. Chemical exposure guidelines for deployed military personnel. Technical Guide 230, version 1.3 (FOUO) 


\section{REPORT DOCUMENTATION PAGE}

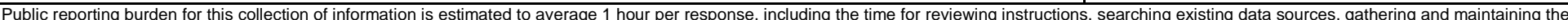

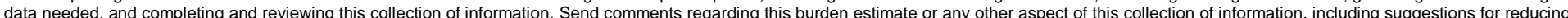

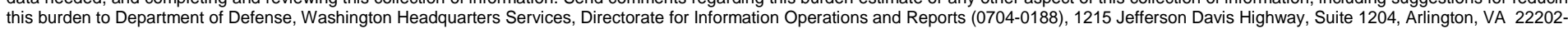

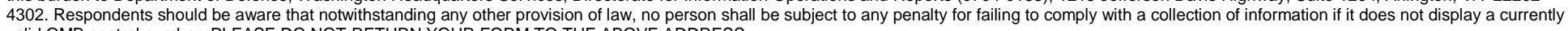
valid OMB control number. PLEASE DO NOT RETURN YOUR FORM TO THE ABOVE ADDRESS.
1. REPORT DATE (DD-MM-YYYY) 17-09-2013
2. REPORT TYPE Final

\section{DATES COVERED (From - To)}

\section{TITLE AND SUBTITLE}

Contingency Base Camp Solid Waste Generation

6. AUTHOR(S)

Stephen D. Cosper, H. Garth Anderson, Kurt Kinnevan, and ByungJ . Kim

\section{PERFORMING ORGANIZATION NAME(S) AND ADDRESS(ES)}

US Army Engineer Research and Development Center (ERDC)

Construction Engineering Research Laboratory (CERL)

PO Box 9005,

Champaign, IL 61826-9005 5a. CONTRACT NUMBER

5b. GRANT NUMBER

\section{5c. PROGRAM ELEMENT}

\section{5d. PROJECT NUMBER}

5e. TASK NUMBER

$622784 \mathrm{~T} 4100$

5f. WORK UNIT NUMBER

$122 \mathrm{G} 16$

8. PERFORMING ORGANIZATION REPORT NUMBER

ERDC/CERL TR-13-17

\section{SPONSOR/MONITOR'S ACRONYM(S)} PM-FSS

US Army Natick Soldier RD\&E Center

15 Kansas St.

Natick, MA 01760-5000

11. SPONSOR/MONITOR'S REPORT NUMBER(S)

\section{DISTRIBUTION I AVAILABILITY STATEMENT}

Approved for public release; distribution is unlimited.

\section{SUPPLEMENTARY NOTES}

\section{ABSTRACT}

Solid waste management is an important engineering function at Forward Operating Bases (FOBs). Due to the contingency nature of base operations and daily life at the FOB, waste generation is likely to be always higher than Continental United States (CONUS) on a per soldier basis. To improve operational effectiveness and efficiency, there is a need to gather baseline information on which to evaluate the performance of new technologies and approaches to solid waste management. To fill this data gap, the Army Study Program funded a group of studies for power, water, and waste management. This specific work characterized and quantified solid waste generation, which includes septage ("blackwater”) generation, at the "per soldier” and base camp level.

\section{SUBJECT TERMS}

Army facilities, contingency base camp, management, operations and management

\section{SECURITY CLASSIFICATION OF:}

\begin{tabular}{|c|c|c|}
\hline $\begin{array}{c}\text { a. REPORT } \\
\text { Unclassified }\end{array}$ & $\begin{array}{c}\text { b. ABSTRACT } \\
\text { Unclassified }\end{array}$ & $\begin{array}{c}\text { c. THIS PAGE } \\
\text { Unclassified }\end{array}$ \\
\hline
\end{tabular}

\begin{tabular}{|c|c|c}
$\begin{array}{c}\text { 17. LIMITATION } \\
\text { OF ABSTRACT }\end{array}$ & $\begin{array}{c}\text { 18. NUMBER } \\
\text { OF PAGES }\end{array}$ & 19 \\
\cline { 3 - 3 } & & \\
SAR & 36 &
\end{tabular}

19a. NAME OF RESPONSIBLE PERSON

19b. TELEPHONE NUMBER (include area code) 